\title{
Mitochondrial Dysfunction and Immune Activation are Detectable in Early Alzheimer's Disease Blood
}

\author{
Katie Lunnon ${ }^{\mathrm{a}, \mathrm{b}, 1}$, Zina Ibrahim ${ }^{\mathrm{a}, \mathrm{b}, 1}$, Petroula Proitsi ${ }^{\mathrm{a}, \mathrm{b}}$, Anbarasu Lourdusamy ${ }^{\mathrm{a}, \mathrm{b}}$, \\ Stephen Newhouse ${ }^{\mathrm{a}, \mathrm{b}}$, Martina Sattlecker ${ }^{\mathrm{a}, \mathrm{b}}$, Simon Furney ${ }^{\mathrm{a}, \mathrm{b}, 3}$, Muzamil Saleem $^{\mathrm{a}, \mathrm{b}}$, Hilkka Soininen ${ }^{\mathrm{c}}$, \\ Iwona Kłoszewska ${ }^{\mathrm{d}}$, Patrizia Mecocci ${ }^{\mathrm{e}}$, Magda Tsolaki ${ }^{\mathrm{f}}$, Bruno Vellas ${ }^{\mathrm{g}}$, Giovanni Coppola ${ }^{\mathrm{h}}$, \\ Daniel Geschwind $^{\mathrm{h}}$, Andrew Simmons ${ }^{\mathrm{a}, \mathrm{b}}$, Simon Lovestone ${ }^{\mathrm{a}, \mathrm{b}}$, Richard Dobson $^{\mathrm{a}, \mathrm{b}, 2}$, \\ Angela Hodges ${ }^{\mathrm{a}, \mathrm{b}, 2, *}$ and on Behalf of the AddNeuroMed Consortium \\ a'Institute of Psychiatry, King's Health Partners Centre for Neurodegeneration Research, King's College London, \\ London, UK \\ ${ }^{\mathrm{b}}$ NIHR Biomedical Research Centre for Mental Health at South London and Maudsley NHS Foundation Trust and \\ Institute of Psychiatry, King's College London, London, UK \\ ${ }^{\mathrm{c}}$ Department of Neurology, University of Eastern Finland and Kuopio University Hospital, Kuopio, Finland \\ ${ }^{\mathrm{d}}$ Medical University of Lodz, Lodz, Poland \\ ${ }^{\mathrm{e}}$ Institute of Gerontology and Geriatrics, University of Perugia, Perugia, Italy \\ f $3 r d$ Department of Neurology, "G. Papanicolaou” Hospital, Aristotle University of Thessaloniki, \\ Thessaloniki, Greece \\ ${ }^{\mathrm{g}}$ INSERM U 558, University of Toulouse, Toulouse, France \\ ${ }^{\mathrm{h}}$ Department of Neurology, Programme in Neurogenetics, David Geffen School of Medicine, University of California \\ at Los Angeles, CA, USA
}

Accepted 25 February 2012

\begin{abstract}
Alzheimer's disease (AD), like other dementias, is characterized by progressive neuronal loss and neuroinflammation in the brain. The peripheral leukocyte response occurring alongside these brain changes has not been extensively studied, but might inform therapeutic approaches and provide relevant disease biomarkers. Using microarrays, we assessed blood gene expression alterations occurring in people with $\mathrm{AD}$ and those with mild cognitive changes at increased risk of developing AD. Of the 2,908 differentially expressed probes identified between the three groups $(p<0.01)$, a quarter were altered in blood from mild cognitive impairment (MCI) and AD subjects, relative to controls, suggesting a peripheral response to pathology may occur very early. There was strong evidence for mitochondrial dysfunction with decreased expression of many of the respiratory complex I-V genes and subunits of the core mitochondrial ribosome complex. This mirrors changes previously observed in AD brain. A number of genes encoding cell adhesion molecules were increased, along with other immune-related genes. These changes are consistent with leukocyte activation and their increased the transition from circulation into the brain. In addition to expression
\end{abstract}

\footnotetext{
${ }^{1,2}$ These authors contributed equally to the work.

${ }^{3}$ Present address: The Institute of Cancer Research, London, UK.

*Correspondence to: Angela Hodges, King's College London, Institute of Psychiatry, De Crespigny Park, London, UK. Tel.: +44 207848 0772; Fax: +44 207848 0632; E-mail: angela.k.hodges@kcl.ac.uk.
} 
changes, we also found increased numbers of basophils in people with MCI and AD, and increased monocytes in people with an $\mathrm{AD}$ diagnosis. Taken together this study provides both an insight into the functional response of circulating leukocytes during neurodegeneration and also identifies potential targets such as the respiratory chain for designing and monitoring future therapeutic interventions using blood.

Keywords: Alzheimer's disease, blood, gene expression pattern analysis, inflammation, late onset, mild cognitive impairment, mitochondria

Supplementary data available online: http://dx.doi.org/10.3233/JAD-111592

\section{INTRODUCTION}

Alzheimer's disease (AD) is the most common form of dementia. It is characterized by slow progressive short term memory loss and the emergence of behavioral symptoms such as psychosis, agitation, apathy, and depression. Patients gradually lose their ability to maintain personal care and death usually occurs 10-15 years following diagnosis. A combination of an increasingly aging population and a current lack of disease-modifying treatments will lead to an overwhelmingly large number of people living with $\mathrm{AD}$ in the coming years with far reaching social and economic consequences [1]. Thus efforts to diagnose and treat disease early, before considerable damage has occurred, are a very high priority.

Probable AD is clinically diagnosed when robust symptoms emerge such as problems with memory, language, perceptual skills, attention, constructive abilities, orientation, problem solving, and functional abilities [2]. At present, diagnosis is only confirmed by postmortem histopathological assessment. Against this gold standard, clinical diagnostic accuracy can vary from fair to excellent (65-96\%) [3-6], highlighting the reality of a disease which is clinically heterogeneous and similar to other disorders. Accurate in-life diagnosis requires a high threshold of disease. Subclinical disease has likely been present for decades before a formal $\mathrm{AD}$ diagnosis is made $[7,8]$. The emergence of mild clinical symptoms such as memory complaints in individuals with intact cognition and normal daily living, which define Petersen's criteria of mild cognitive impairment (MCI) [9], may reflect the gradual and progressive appearance of plaques, neurofibrillary tangles, cellular dysfunction, and loss of specific neuronal cells which characterize AD. However, these symptoms can sometimes represent another neurological disease or be due to normal aging, as is the case for about $25 \%$ of people with MCI [10].

Plaques and neurofibrillary tangles are pathological hallmarks of $\mathrm{AD}$ and their generation is believed to lead to the disruption of calcium homeostasis and neuronal synapses, loss of connectivity, increased reactive oxygen/nitrogen species, and altered plasticity in vulnerable brain regions, culminating in progressive neuronal cell death. Inappropriate neuroinflammation [11-13] and mitochondrial dysfunction [14-17] are consistent features of AD pathology in brain and are important mechanisms through which toxicity may be propagated.

Changes in $\mathrm{AD}$ are not just restricted to the brain. A number of genes have altered abundance in AD blood, some of which are sufficient to specifically and accurately classify disease [18-20]. Preliminary evidence suggests these changes may precede AD diagnosis [21] but this has yet to be extensively investigated in people with MCI. Mitochondria from peripheral blood cells such as platelets and lymphocytes are dysregulated [16, 22-24] and leukocytes from AD patients are far more responsive to activation signals [25]. Some AD blood cell vulnerabilities and diseaseassociated changes may be linked to changes in levels of amyloid- $\beta$ (A $\beta$ ) peptides in plasma [26-29]. For example, when ex vivo blood cells from $\mathrm{AD}$ patients are treated with $A \beta_{1-42}$, there is a failure to upregulate MGAT3, a protein involved in A $\beta$ clearance [30]. MGAT3 may be useful as a prognostic biomarker of disease deterioration [31]. Paralleling these alterations in blood cell activity, changes in circulating cytokines, chemokines, and other proteins, indicating activation of the peripheral innate immune system occur in people with MCI and AD [32-38].

A good strategy for further understanding disease and treatment development might be to identify important disease associated pathways in peripheral blood. Blood is an easily accessible tissue which can be used to assess changes occurring early in disease. Using microarrays and a unique collection of blood samples, with extensive demographic, clinical, and imaging data available, we have identified differentially expressed genes and altered biological processes in blood samples from people with MCI and AD. Changes in blood, 
which we believe reflect the disease processes occurring in brain, could enable these cells to be used for future design and monitoring of treatments against disease-relevant biological processes.

\section{METHODS AND MATERIALS}

\section{Subjects and samples}

Blood samples for full blood cell count and mRNA analyses were taken from subjects participating in the AddNeuroMed study [39-41], involving six study sites across Europe (London, Kuopio, Lodz, Perugia, Thessaloniki, and Toulouse) or the London Dementia Case Register (London). All sample and data analyses were undertaken in London, with the exception of the microarrays, which were processed at the University of California in Los Angeles. Informed consent according to the Declaration of Helsinki (1991) and ethical approval were obtained at each study site, with all sites following an agreed standardized operating procedure for subject assessment and sample collection. Subjects were nominally assigned to an AD, MCI, or normal elderly control group as we have previously described [40, 42] and is summarized as follows. Cases with probable AD were identified from primary and secondary care services and diagnosed using the NINCDS-ADRDA criteria [2] and Diagnostic and Statistical Manual of Mental Disorders (DSM-IV) [43]. MCI subjects were recruited from local memory clinics and as such the MCI cohort was expected to be composed largely of subjects with a likely AD-endpoint. All MCI subjects reported problems with memory, corroborated by an informant, but had normal activities of daily living as specified in the Petersen's criteria of amnestic MCI [44, 45] and scored 0.5 on the Total Clinical Dementia Rating Scale (CDR) or had a memory score of 0.5 or 1 [46]. Within 2 years of the baseline visit, some MCI subjects progressed to a clinical diagnosis of AD (MCI-AD), while others remained MCI (MCI-MCI). Normal elderly controls, defined as having no evidence of cognitive impairment, were recruited from primary care services and elsewhere.

Each subject underwent a semi-structured interview to collect demographic and medical information. They completed neuropsychological assessments including the Mini Mental State Examination [47], Global Deterioration Scale [48], and CDR [46]. Additionally, AD patients were assessed by the Alzheimer's Disease Assessment Scale-Cognitive subscale [49], the caregiver rated Neuropsychiatric Inventory scale [50], and the caregiver rated Alzheimer's Disease Cooperative Study-Activities of Daily Living Inventory [51]. Control and MCI subjects were further assessed using the CERAD battery [52]. Subjects were excluded from the study if they were younger than 65 years, had significant neurological or psychiatric illness other than $\mathrm{AD}$, significant systematic illness or organ failure, or a geriatric depression rating scale score $\geq 4 / 5$ [53]. Subject characteristics are summarized in Table 1.

\section{Full blood cell count analysis}

Approximately $3 \mathrm{ml}$ of venous blood was collected in $\mathrm{K}_{3}$ EDTA vacutainer tubes (MidiMeds Limited). Full blood cell count analysis was performed at the Department of Haematological Medicine at King's College Hospital using an automated counter, according to standard clinical practice. Samples within the normal range $\pm 10 \%$, were available from 125 normal elderly controls, 41 MCI subjects, and 73 AD subjects. Extreme values outside the normal range for any subject may represent an underlying episode of infection or peripheral inflammation and were therefore excluded from further analysis. Following $\log _{10}$ transformation of the data, linear regression was carried out to assess the effect of disease status on individual leukocyte populations, adjusting for age, gender and other blood cell types. All statistical analyses were performed in SPSS or STATA.

\section{Whole blood RNA extraction}

Blood ( $2.5 \mathrm{ml})$ was collected in PAXgene blood RNA vacutainer tubes (BD Diagnostics). The tube was inverted 8-10 times following blood collection, stored at $-20^{\circ} \mathrm{C}$ for $24 \mathrm{~h}$ and then $-80^{\circ} \mathrm{C}$ until RNA extraction. Where necessary, samples were shipped on dry ice to London prior to RNA extraction. RNA was extracted from all samples from their first visit and within two years of collection as follows. After thawing PAXgene tubes overnight at room temperature, total RNA was extracted using the PAXgene blood RNA kit (Qiagen), according to the manufacturer's protocol. The quality of the RNA was determined using the 2100 Bioanalyser (Agilent Technologies). The average RNA integrity number (RIN) across all samples was 8.8, standard deviation 0.7 . Only samples with a RIN $>7.0$ were used in the analysis. 
Table 1

Subject characteristics of individuals used in Microarray and Blood cell count analyses

\begin{tabular}{|c|c|c|c|c|}
\hline Microarray analysis & Control & MCI & MCI-AD & $\mathrm{AD}$ \\
\hline Samples run on illumina BeadChips & 116 & 83 & 44 & 113 \\
\hline Samples used in analysis ${ }^{\mathrm{a}}$ & 105 & 78 & 42 & 104 \\
\hline Gender (M/F) & $43 / 62$ & $39 / 39$ & $14 / 28$ & $32 / 72$ \\
\hline Age in years $( \pm S D)$ & $72.4(6.4)$ & $74.3(5.6)$ & $74.6(6.8)$ & $75.4(6.7)$ \\
\hline Disease duration in years $( \pm \mathrm{SD})$ & $\mathrm{n} / \mathrm{a}$ & $\mathrm{n} / \mathrm{a}$ & $\mathrm{n} / \mathrm{a}$ & $3.6(2.1)$ \\
\hline $\operatorname{MMSE}( \pm \mathrm{SD})$ & $29(1.2)$ & $27(1.7)$ & $26(2.3)$ & $21(4.6)$ \\
\hline ADAS-cog $( \pm S D)$ & $\mathrm{n} / \mathrm{a}$ & $\mathrm{n} / \mathrm{a}$ & $\mathrm{n} / \mathrm{a}$ & $23(10.0)$ \\
\hline CDR sum of boxes $( \pm \mathrm{SD})$ & $0(0.2)$ & $1.3(0.8)$ & $2.1(1.1)$ & $6.5(3.3)$ \\
\hline \multicolumn{5}{|l|}{ Blood cell count analysis } \\
\hline Samples with available blood cell count data & 125 & 41 & $\mathrm{n} / \mathrm{a}$ & 73 \\
\hline Gender $(\mathrm{M} / \mathrm{F})$ & $45 / 80$ & $24 / 17$ & $\mathrm{n} / \mathrm{a}$ & $32 / 41$ \\
\hline Age in years $( \pm S D)$ & $77.7(6.3)$ & $79.0(4.6)$ & $\mathrm{n} / \mathrm{a}$ & $80.3(6.4)$ \\
\hline Disease duration in years $( \pm \mathrm{SD})$ & $\mathrm{n} / \mathrm{a}$ & $\mathrm{n} / \mathrm{a}$ & $\mathrm{n} / \mathrm{a}$ & $4.3(3.8)$ \\
\hline $\operatorname{MMSE}( \pm \mathrm{SD})$ & $29.0(1.2)$ & $27.8(1.5)$ & $\mathrm{n} / \mathrm{a}$ & $21.6(5.4)$ \\
\hline $\operatorname{ADAS}-\operatorname{Cog}( \pm \mathrm{SD})$ & $\mathrm{n} / \mathrm{a}$ & $\mathrm{n} / \mathrm{a}$ & $\mathrm{n} / \mathrm{a}$ & $19.3(9.4)$ \\
\hline CDR sum of boxes $( \pm \mathrm{SD})$ & $0.2(0.3)$ & $1.3(0.7)$ & $\mathrm{n} / \mathrm{a}$ & $6.3(3.2)$ \\
\hline
\end{tabular}

${ }^{a}$ Microarray data from $1 \mathrm{AD}$ and 1 Control were excluded from further analyses because of a discrepancy between XIST expression gender assignment and the original gender recorded for these participants; 20 samples were excluded due to an unacceptably low rate of detection on the BeadChip; 2 MCIs were removed from further analyses because one subsequently converted to a diagnosis of Frontotemporal Dementia, while the other case was subsequently diagnosed with a large meningioma. $1 \mathrm{AD}$ was removed from further analyses due to a revoked diagnosis, and $1 \mathrm{AD}$ was removed due to a low RNA Integrity Number (RIN). Control subjects who converted to an MCI diagnosis $(N=4)$ and $\mathrm{MCI}$ subjects who converted to an AD diagnosis within 2 years post-sampling $(N=42)$ were analysed as their status at sampling, unless indicated in the text; MMSE, Mini Mental State Examination; CDR, Clinical Dementia Rating scale; Alzheimer's Disease Assessment Scale-Cognitive subscale (ADAS-Cog).

\section{Microarray expression analysis and pre-processing}

A total of 356 (116 control, $127 \mathrm{MCI}$, and $113 \mathrm{AD}$ ) RNA samples (Table 1) were processed on Illumina Human HT-12 v3 Expression BeadChips (Illumina) according to the protocol supplied by the manufacturer. These chips contain 48,803 probes designed using data from RefSeq (Build 36.2, Rel 22) and the UniGene (Build 199) databases. cDNA was synthesized using $200 \mathrm{ng}$ total RNA followed by amplification and biotinylation of cRNA and hybridization according to the protocol supplied with the Illumina TotalPrep RNA Amplification Kit (Ambion). Following hybridization, gene expression values were obtained using the Lumi package within Bioconductor which involves variance stabilization and quantile normalization [54]. Outlier BeadChips with very low detection rate $(<80 \%)$, discrepancy in XIST gene expression and recorded gender or serious co-morbid disease which came to light on follow-up visits, were removed from further analyses leaving 329 chips in the final analysis. Expression of XIST (ILMN_26235) is low or absent in males, since the XIST gene is expressed almost exclusively from the active $\mathrm{X}$ chromosome present only in females. Probes that did not vary across samples (largely representing non-expressed genes in blood) were removed from subsequent analyses, leaving 19,161 probes. Gene expression data was adjusted for age, gender, RNA quality (RIN), and study site and the residuals used for subsequent analyses. Gene expression differences between diagnostic groups (control, MCI, and AD) were statistically evaluated using linear models for microarray analyses (Limma) [55]. $P$-values were adjusted for multiple testing according to the false discovery rate (FDR) procedure of Benjamini and Hochberg and differentially expressed genes were selected at FDR <0.01 [56] (supplementary Table 1; available online: http://www.j-alz.com/issues/30/vol30-3. html\#supplementarydata04). All statistical analyses were performed in the statistical environment $\mathrm{R}$ using Bioconductor packages.

\section{Creation of weighted co-expression networks}

We utilized the $\mathrm{R}$ package for weighted gene co-expression networking analysis (WGCNA) [57], to identify clusters (modules) of highly connected (correlated) genes. A full glossary of terms to describe the analysis is available in supplementary data and at the WGCNA web site (http://www.genetics.ucla.edu/labs/ horvath/CoexpressionNetwork/Rpackages/WGCNA/). The underlying hypothesis is that such modules are likely to possess a common function [58]. We restricted the analysis to 9,970 of the 19,161 probes 
after (i) removing genes that were not expressed in any sample, (ii) only using probes detected in at least $80 \%$ of samples in each diagnostic group, and (iii) limiting to those annotated with Entrez Ids.

We estimated the connectivity of probes using a pairwise Pearson correlation between all expressions profiles resulting in an adjacency matrix. We applied the topological overlap function to transform this matrix into a topological overlap matrix (TOM) adjacency (see glossary in supplementary data). This replaces the original adjacencies with an interconnected measure based on shared neighbors. To reduce noise, we further filtered the probes to only include those whose connectivity was above the median connectivity on the TOM, leaving 4,985 probes for subsequent analyses.

The modules were created dynamically by clustering the TOM using the Ward linkage clustering algorithm [59]. Each module is represented by an arbitrary color assigned by the analysis software according to size. We constructed signed networks, which preserve the sign of correlations (i.e., direction of expression change) among the expression profiles. The connection strength between two genes was regulated by a soft threshold $\beta=15$, chosen by empirical assessment of the network topology [57]. Introducing a soft threshold allows generation of robust results by maintaining gene co-expression information. Modules were represented by a single expression profile, the module eigengene (ME), which allowed us to explore module behavior with respect to traits such as structural changes in the brain. MEs represent the first principal component for genes within each module. The MEs were used to estimate the module membership (MM) for each probe and thereby the extent to which a given probe conforms to the characteristics of the module. The correlation between individual gene expression values and ME is used to calculate MM [58].

\section{Module-trait correlations}

To understand the significance of the modules for disease, we correlated the MEs with discrete phenotypic traits including: MCI throughout study (MCI-MCI), MCI who were later diagnosed with $\mathrm{AD}$ within a two year follow-up (MCI-AD), AD at baseline (AD), and $\mathrm{AD}$ at baseline and/or follow-up (ALL AD) and Disease Severity, which discretises the severity of the disease using the following coding: control (0), MCI-MCI (1), MCI-AD (2), and AD (3). The MEs were also correlated with structural magnetic resonance imaging traits (sMRI) including brain volume and cortical thickness, previously shown to be relevant in $\mathrm{AD}[42,60-62]$ and available for the same individuals: right entorhinal volume, left entorhinal volume, total entorhinal volume, mean entorhinal thickness, ventrical volume, left hippocampal volume, right hipppocampal volume, total hippocampal volume, and whole-brain volume. A full description of how the brain volume and cortical thickness measures were generated for these subjects has been detailed previously $[61,62]$. The module-sMRI trait correlations were restricted to a subset of 239 subjects for which a full set of trait information was available. A correlation between each module and trait was considered significant at $p<1 \times 10^{-3}$ (Fig. 3).

The gene significance (GS) of a gene describes the strength of the correlation between the probe and the trait in question while the MM quantifies the extent to which a gene conforms to the characteristics of a module (i.e., it correlates with the ME). The combination of MM and GS identifies genes which play important roles in a given network module and are furthermore significant for the clinical trait in question. The gene significance and module memberships for the genes with respect to the traits: MCI-MCI, MCI-AD, AD, ALL AD, and Disease Severity are listed in supplementary Tables 2-7. We plotted the MM against GS for traits that correlated with MEs and highlighted the genes that exhibit higher-than-median MM and GS with respect to the trait. The pink, brown, and turquoise modules were plotted against the MCI-MCI trait because their MEs show significant correlation with MCI-MCI in Fig. 3. For the same reason, the black, blue and red modules were plotted against the disease severity (DS) trait.

\section{Gene enrichment analysis}

We conducted enrichment analyses to describe the functional characteristics of probes assigned to each of the disease-associated modules. We tested for enrichment of Gene Ontology (GO) terms associated with biological processes, molecular functions, and cellular compartments. We also performed a gene set enrichment analysis against KEGG Pathways using probes with both higher-than-median MM and GS for each module, highlighted in green in Fig. 5. The test was performed using DAVID (http://david.abcc.ncifcrf.gov/), which calculates significance of probe over-representation in particular pathways [63]. We considered a pathway significant at $p<5 \times 10^{-4}$. We also investigated whether groups of genes known to have direct disease- 
association or association with increased disease risk, had higher-than-median MM and GS for any module. The candidate gene list is presented in supplementary Table 8 which includes the top 12 genes associated with increased AD risk collated from GeneWide Association Studies (GWAS) and available at http://www.alzgene.org/ [64].

\section{Module preservation between blood and brain}

We first tested the blood modules for enrichment using a large collection of brain-related gene sets [65-86] where significance was computed using a hypergeometric test. To further investigate the extent by which disease associated changes present in peripheral blood reflect changes in $\mathrm{AD}$ brain we compared our blood modules with two human AD brain expression datasets in more detail $[77,87]$. To assess module preservation, we used two statistical measures, the $\mathrm{Z}$-statistic and the median rank. The value of the $\mathrm{Z}$ statistic is directly proportional to how preserved the blood module is in the brain data set: the higher the value of a $\mathrm{Z}$-statistic, the stronger the evidence that the module displays significantly higher preservation than expected by chance alone. Langfelder and colleagues suggests that a Z-statistic $>10$ indicates a highly-preserved module, $2<\mathrm{Z}$-statistic $<10$ indicates a somewhat preserved module while a Z-statistic $<2$ indicates very low confidence that the module is preserved [88]. Despite its usefulness, the Z-statistic tends to give a better rank to modules of larger sizes. We therefore also use the median rank, which is based on the observed preservation statistics (as opposed to the $\mathrm{Z}$-statistics or $p$-value), and because it is less sensitive to the size of the module, enabled us to compare the relative preservation between modules. A module with lower median rank suggests greater preservation than a module with a higher median rank.

Preservation between blood and brain was explored for both statistics with respect to two network properties: network density and network connectivity. To ascertain preservation of network density, we examined the modules as a whole and determined whether densely-connected modules in blood remained densely connected in brain. To determine the preservation of network connectivity, we examined the patterns of connectivity at the probe level for each module in blood and provided a score which determined whether highly-connected probes central to the blood network (also termed hub genes) remained highly-connected in brain. Results are reported as Z-density, Z-connectivity and Z-summary (the average of Z-density and
Z-connectivity) and median rank density, median rank connectivity and median rank summary.

\section{Blood cell types with over-represented changes in gene expression}

To characterize whether particular blood cell populations were more affected in disease, probes with significantly altered expression in $\mathrm{AD}(n=2,270$ with FDR $<0.01$ ) were mapped on to a list of probes previously reported to be enriched in particular blood cell types [89]. Over- or under-representation of significantly altered genes was tested using the Pearson's chi-squared test, or the Fisher's exact test if the number of probes was $<10$. To increase confidence in our results, we also tested whether more cell lineage probes attained a given $p$-value than would be expected by chance. This was achieved by randomly selecting 2,908 of the 19,161 probes used in the analysis and repeating the analysis for each cell-type specific list for 10,000 permutations. We further tested for just over-representation of significantly altered probes in particular blood cells in AD blood using a hypergeometric probability test.

\section{RESULTS}

\section{Disease-associated gene expression differences}

A large number of gene expression changes were observed in blood from MCI and AD subjects compared to normal elderly controls. Of the 2,908 differentially expressed probes identified between the three groups (FDR corrected $p<0.01$ ), around a quarter were similarly altered in blood from MCI and AD subjects, relative to controls (Fig. 1 and supplementary Table 1). The probes which reached the greatest significance were predominantly down-regulated, although overall, there were roughly equal numbers of significantly up- and down-regulated probes below the nominal $p$-value threshold.

Across blood samples, expression patterns could be clustered together in to ten distinct modules, containing between 171 (magenta) to 1,179 (turquoise) probes (Fig. 2 and supplementary Tables 2-7). Modules are assigned an arbitrary color by the analysis software according to their size. Six of these modules had significant differences in mean ME expression between subject groups, with the red, black, pink, brown, blue, and turquoise modules achieving $p$-values $3.7 \times 10^{-9}, 2.7 \times 10^{-13}, 3.7 \times 10^{-5}$, $4.2 \times 10^{-7}, 2.6 \times 10^{-5}$, and $8.6 \times 10^{-9}$, respectively, 


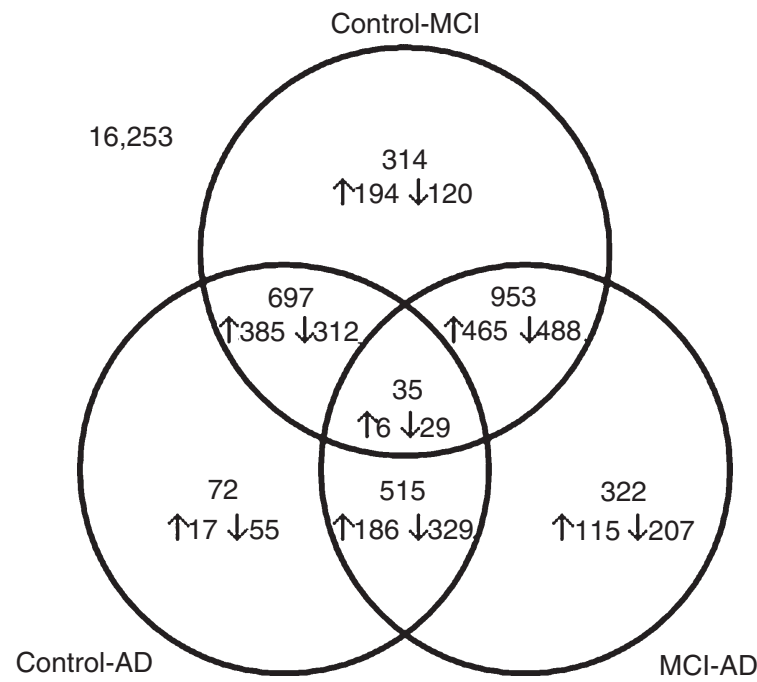

Fig. 1. Number of probes with differential expression between AD, MCI, and control blood samples, FDR corrected $p<0.01$. Direction of change refers to an increase $(\uparrow)$ or decrease $(\downarrow)$ in expression of control relative to $\mathrm{MCI}$ blood (Control-MCI), control relative to AD (Control-AD), or MCI relative to control (MCI-AD), as indicated.

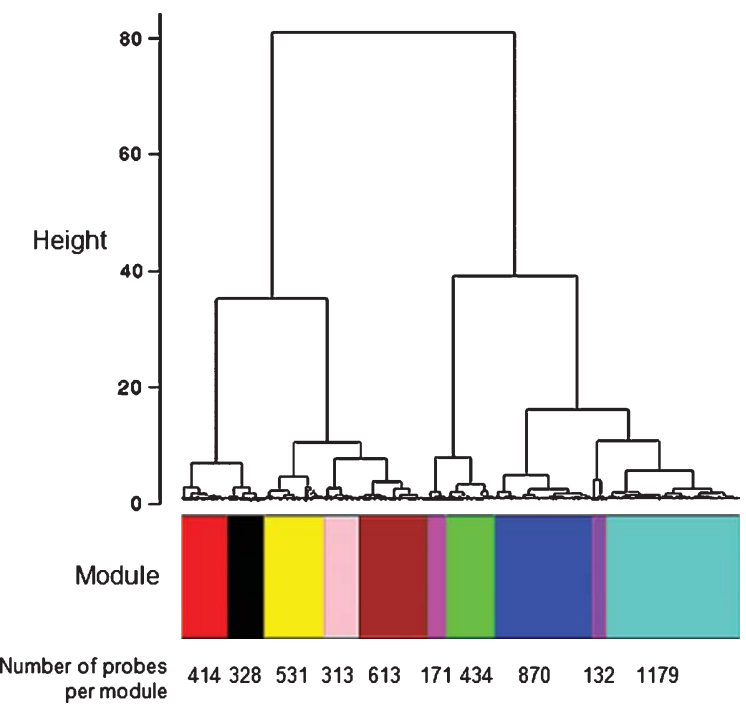

Fig. 2. Clustering dendrogram showing modules identified using blood expression data from control, MCI, and AD subjects. Modules are assigned an arbitrary color by the analysis software according to their size: Red, Black, Yellow, Pink, Brown, Magenta, Green, Blue, Purple, and Turquoise. The numbers of probes are indicated below each module.

in Kruskal Wallis tests. Of these, the red, black, pink, and brown modules were down-regulated in MCI-MCI, and/or MCI-AD, AD, or Disease Severity, relative to controls (Figs. 3 and 4). As expected, many of the structural MRI traits were positively correlated with genes in these modules, whereby reductions in brain volume and cortical thickness correlated with reduced gene expression (Fig. 3). Where these modules differed from each other was in their relative levels of expression in AD subjects. Genes within the black and red modules continued to display reduced expression in blood from AD subjects, similar to that seen in MCI subjects (e.g., ALL AD, $r=-0.29$, correlation $p$-value $p=8 \times 10^{-8}$, black module) (Figs. 3, 4a and $b$ ), while expression in the brown and pink modules abated in AD patients, achieving mean levels of expression more similar to control subjects (e.g., ALL AD, $r=-0.03$, correlation $p$-value $p=0.6$, brown module) (Figs. 3, 4c and d).

The blue and turquoise modules displayed the opposite pattern. They were upregulated in MCI-MCI, MCI-AD, AD, and/or with Disease Severity relative to controls (Figs. 3 and 4). Many of the sMRI traits displayed negative correlation with these two modules (Fig. 3). The blue and turquoise modules differed in their relative levels of expression in $\mathrm{AD}$ subjects. Genes within the blue module continued to display upregulated expression in blood from $\mathrm{AD}$ subjects, similar to that seen in MCI subjects (ALL AD, $r=0.21$, correlation $p$-value $p=1 \times 10^{-4}$ ) (Figs. 3 and $4 \mathrm{e}$ ), while expression in the turquoise module appeared to abate in $\mathrm{AD}$ patients, achieving mean levels of expression not significantly different from control subjects (All $\mathrm{AD}, r=0.056$, correlation $p$-value $p=0.3$ ) (Figs. 3 and $4 \mathrm{f})$.

The turquoise, brown, and pink modules displayed changes in MCI subjects which appeared to return toward normal levels in people clinically diagnosed with AD (Figs. 3 and 4). We therefore repeated the Kruskal Wallis tests after excluding the control group to test for MCI-AD differences. There were significant differences in the pink $\left(p\right.$-value $\left.=8.7 \times 10^{-5}\right)$, brown $\left(p\right.$-value $\left.=7 \times 10^{-4}\right)$, and turquoise $\left(p\right.$-value $\left.=7 \times 10^{-4}\right)$ modules between subjects with MCI and AD.

\section{Functional identity of genes with altered expression}

The GO enrichment test [90] for each of the disease-associated blood modules revealed important associations for the red, black, pink, brown, blue, and turquoise modules with particular GO terms, thus providing a functional characteristic to each module. For each module, GO terms with a $p$-value $<0.05$ are summarized in Table 2. Overall, there were strong associations in the red module with lower 


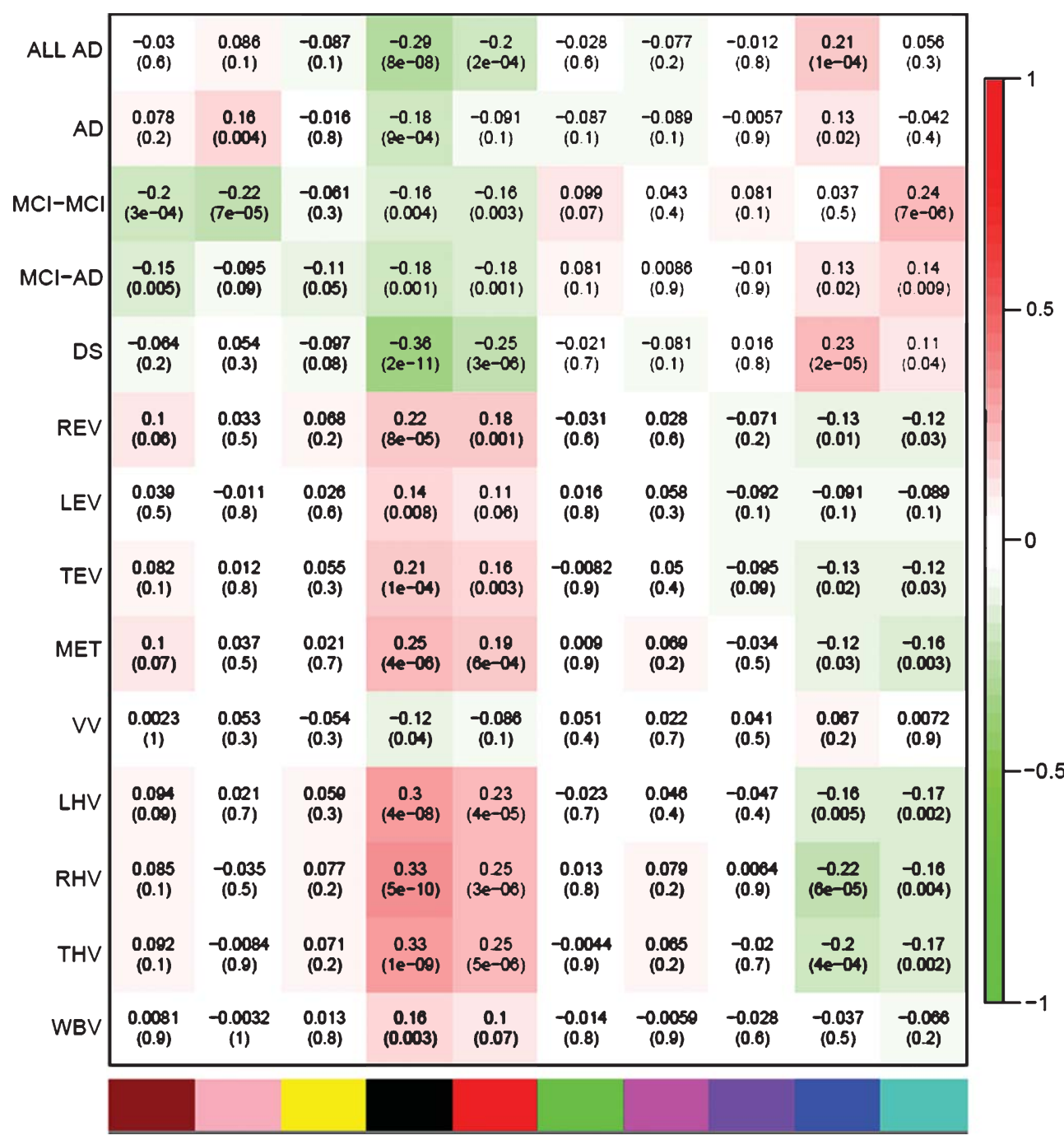

Fig. 3. Heatmap of module-trait correlations. The first four traits represent correlation of disease diagnosis (AD or MCI) relative to normal elderly controls, within each module. MCI was further divided into subjects who subsequently converted to an AD diagnosis within 2 years of sampling (MCI-AD) and those who did not (MCI-MCI). A further AD group (ALL AD) represents any subject who received a diagnosis of $\mathrm{AD}$ during the two years of the study. Disease Severity (DS) was also analyzed. The remaining traits represent structural imaging measures of regional brain volume or cortical thickness: right entorhinal volume (REV), left entorhinal volume (LEV), total entorhinal volume (TEV), mean entorhinal thickness (MET), ventrical volume (VV), left hippocampal volume (LHV), right hipppocampal volume (RHV), total hippocampal volume (THV) and whole-brain volume (WBV). For each module-trait pair the top-most value is the Pearson correlation coefficient while the second (bracketed) value is the correlation $p$-value. The cell color represents the strength and direction of the correlation. Modules are assigned an arbitrary color by the analysis software according to their size.

ribosomal function and translation, the black module with decreased mitochondrial function and ribosomal function and translation, the pink module with lower secretory and endocytic function, the brown module with decreased metabolic processes, the blue module with altered immune function, and the turquoise module with activation of transcription, in disease.

To further explore the genes that were most representative of each module (module hubs) and were also the most associated with disease-related traits, we correlated module membership (MM) and gene significance (GS), and selected probes which exhibited higher-than-median MM and GS and determined their enrichment in KEGG pathways (probes highlighted in green in Fig. 5). The scatter plots of GS and MM (Fig. 5) show concordance with the results presented in the heat map (Fig. 3): the more hub-like a probe is, the greater its correlation with the trait in 

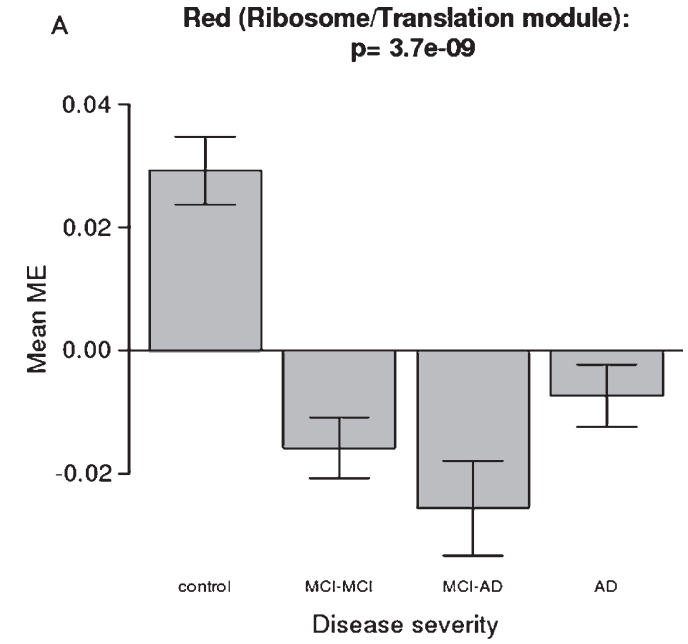

C Pink (Secretory/Endocytosis module): $p=3.7 e-05$

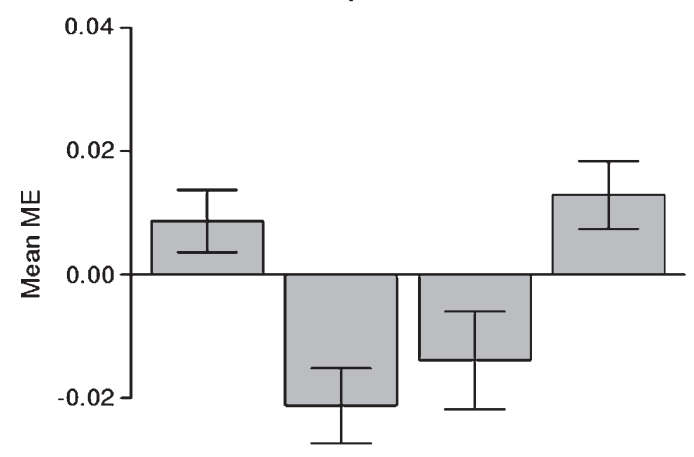

control

MCI-MCI MCI-AD

Disease severity

E Blue (Immune module):

$p=2.6 e-05$

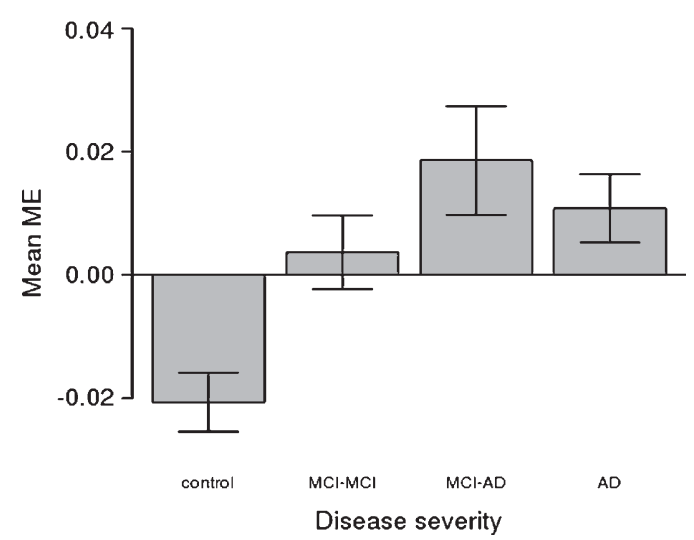

B Black (Ribosome/Mitochondria module): $p=2.7 e-13$

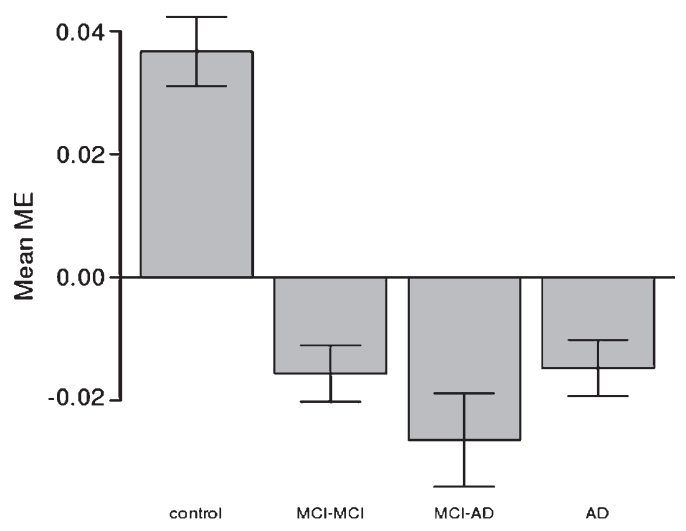

Disease severity

D

Brown (Metabolic module):

$p=4.2 e-07$

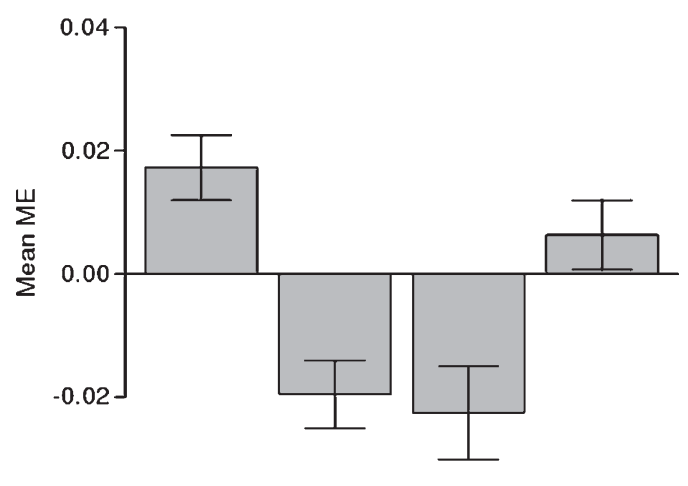

control $\mathrm{MCl}-\mathrm{MCl} \quad \mathrm{MCl}-\mathrm{AD}$

Disease severity

F Turquoise (Transcription module):

$p=8.6 e-09$

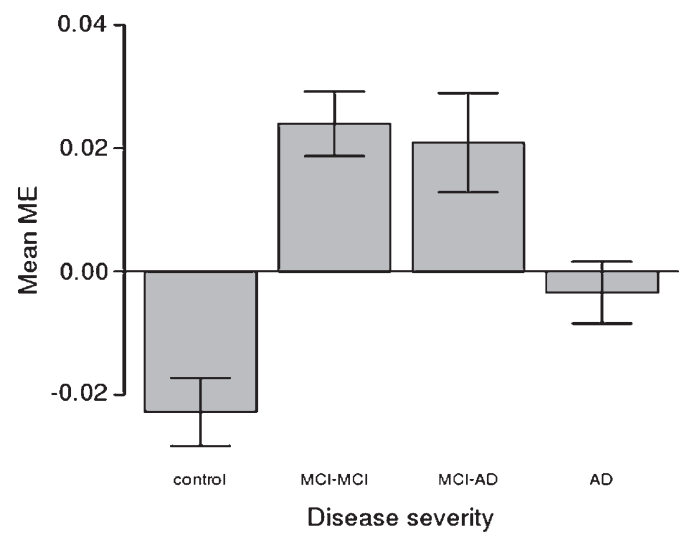

Fig. 4. Boxplots showing the mean module eigengene (ME) expression for the A). Ribosome/Translational, B) Ribosome/Mitochondrial, C) Secretory/Endocytosis, D) Metabolic, E) Immune, and F) Transcription-related modules. MEs represent the first principal component of the module gene members. Significance of differences in mean ME expression for each disease group determined by Kruskal Wallis tests. The mean MEs were compared across diagnostic category: normal elderly control, AD and MCI. MCI was further divided into subjects who subsequently converted to an AD diagnosis within 2 years of sampling (MCI-AD) and those who did not (MCI-MCI). The most significant modules $\left(p<1 \times 10^{-4}\right)$ are represented in A to $\mathrm{F}$. 
Table 2

GO enrichment test for each blood module revealing important associations between genes within each module

\begin{tabular}{ll}
\hline Module & GO term names \\
\hline $\operatorname{Red}^{\mathrm{a}}$ & $\begin{array}{l}\mathbf{C C}^{\mathrm{b}} \text { ribosome, ribonucleoprotein complex, cytosolic ribosome, mitochondrion, cytosolic small ribosomal } \\
\text { subunit, cytosolic part, intracellular part, intracellular organelle, intracellular membrane-bounded organelle, } \\
\text { small ribosomal subunit }\end{array}$
\end{tabular}

Ribosome/Translation

$\mathbf{B P}^{\mathrm{c}}$ cellular metabolic process, translation, metabolic process, cellular biosynthetic process, cellular macromolecule biosynthesis process, gene expression, macromolecule biosynthesis process, biosynthetic process, positive regulation of helicase activity, response to redox state

$\mathbf{M F}^{\mathrm{d}}$ structural constituent of ribosome, non-membrane spanning protein tyrosine phosphatise activity, oxidoreductase activity, acting on NADH or NADPH, quinone or similar compound as acceptor, NADPH: quinine reductase activity, structural molecule activity, serine-type peptidase activity, serine hydrolase activity, ATPase activity, peptidyl-prolyl cis-trans isomerase activity, transferase activity, transferring alkyl or aryl (other than methyl) groups

Black $^{\mathrm{a}} \quad$ CC $^{\mathrm{b}}$ Ribosome, ribonucleoprotein complex, mitochondrion, mitochondrial part, mitochondrial inner membrane, organelle inner membrane, mitochondrial membrane, mitochondrial envelope, intracellular organelle, respiratory chain

Ribosome/Mitochondria $\quad \mathbf{B P}^{\mathrm{c}}$ translation, oxidative phosphorylation, generation of precursor metabolites and energy, mitochondrial electron transport, NADH to ubiquinone, ATP synthesis coupled electron transport, mitochondrial ATP synthesis coupled electron transport, respiratory electron transport chain, cellular respiration, ribonucleoprotein complex biogenesis, electron transport chain

$\mathbf{M F}^{\mathrm{d}}$ structural constituent of ribosome, structural molecule activity, hydrogen ion transmembrane transporter activity, NADH dehydrogenase activity, NADH dehydrogenase (ubiquinone) activity, monovalent inorganic cation transmembrane transporter activity, oxidoreductase activity, acting on NADH or NADPH, quinone or similar compound as acceptor, oxidoreductase activity, acting on NADH or NADPH, RNA binding, oxidoreductase activity

Pink $^{\mathrm{a}}$

$\mathbf{C C}^{\mathrm{b}}$ secretory granule membrane, endomembrane system, clathrin-coated vesicle Golgi apparatus, endosome membrane, synaptic vesicle

Secretory/Endocytosis $\quad \mathbf{B P}^{\mathrm{c}}$ post-translational protein modification, protein amino acid phosphorylation, protein modification process, activation of innate immune response, regulation of synaptic plasticity, regulation of long-term neuronal synaptic plasticity, phosphate metabolic process, regulation of synaptic transmission, nuclear import, regulation of neuronal synaptic plasticity

$\mathbf{M F}^{\mathrm{d}}$ GDP binding, GTPase activity, cAMP binding, co-SMAD binding, catalytic activity ligase activity, purine nucleotide binding, phosphoprotein phosphatase activity, AMP binding, long-chain fatty acid-CoA ligase activity

Brown $^{\mathrm{a}}$

$\mathbf{C C}^{\mathrm{b}}$ intracellular membrane-bounded organelle, membrane-bounded organelle, intracellular, intracellular part, Golgi apparatus, centriole, endosome membrane, organelle membrane, recycling endosome, intracellular organelle

Metabolic $\quad$ BP $\mathbf{P}^{\mathrm{c}}$ amino sugar metabolic process, establishment of protein localization, steroid hormone receptor signaling pathway, protein transport, glucosamine metabolic process

$\mathrm{N}$-acetylglucosamine metabolic process, cellular aromatic compound metabolic process regulation of anti-apoptosis, intracellular receptor mediated signaling pathway

$\mathbf{M F}^{\mathrm{d}}$ protein-L-isoaspartate (D-aspartate) O-methyltransferase activity, solute:hydrogen symporter activity, nucleotide-sugar transmembrane transporter activity, O-methyltransferase activity, beta-N-acetylhexosaminidase activity, polynucleotide adenylyltransferase activity, peptide hormone receptor binding, sugar:hydrogen symporter activity, 7 S RNA binding, hydrolase activity, acting on carbon-nitrogen (but not peptide) bonds, in linear amides

Blue $\quad$ C $C^{\mathrm{b}}$ plasma membrane, membrane, plasma membrane part, intrinsic to membrane, integral to plasma membrane, intrinsic to plasma membrane, integral to membrane, membrane part, cell-substrate adherens junction

Immune $\quad \mathbf{B P}^{\mathrm{c}}$ defense response, signal transduction, inflammatory response, response to wounding intracellular signaling pathway, response to stimulus, immune response, immune system process, response to stress, cell surface receptor linked signaling pathway

$\mathbf{M F}^{\mathrm{d}}$ signal transducer activity, receptor activity, transmembrane receptor activity, lipid binding, phospholipid binding, cytokine receptor activity, phosphotransferase activity, alcohol group as acceptor, enzyme activator activity, receptor signaling protein activity, cytokine binding

Turquoise $^{\mathrm{a}} \quad \mathbf{C C}^{\mathrm{b}}$ nucleoplasm part, intracellular organelle part, nucleoplasm, nuclear lumen, nuclear part, protein complex, intracellular membrane-bounded organelle, membrane-bounded organelle, intracellular organelle, MLL1 complex

$\mathbf{B P}^{\mathrm{c}}$ none

Transcription

$\mathbf{M F}^{\mathrm{d}}$ protein binding, transcription coactivator activity, transcription activator activity, transcription regulator activity, transcription cofactor activity, binding, transcription factor binding, molecular_function, methyltransferase activity, transferase activity

${ }^{\mathrm{a}}$ Terms with a $p$-value $<0.05$ are summarized; ${ }^{\mathrm{b}} \mathrm{CC}$ : Cellular Components; ${ }^{\mathrm{c}} \mathrm{BP}$ : Biological Processes; ${ }^{\mathrm{d}} \mathrm{MF}$ : Molecular Functions. 
question. In the turquoise (transcription) and blue (immune) modules (Fig. 5E and F), probes highlighted in green are in the top-right because these modules showed a positive correlation with the trait, thus making high gene significance a positive value. For all other modules (Fig. 5A-D), high gene significance is negative as the modules showed negative correlation with the corresponding trait and therefore probes highlighted in green are in the bottom-right area instead.

The most significantly altered genes in MCI and $\mathrm{AD}$ blood were in the black (ribosome/mitochondria) module and compared to other modules, this module (probes filtered for high MM and GS) also had the most significant over-representation of genes enriched in KEGG pathways including the AD pathway (supplementary Tables 3 and 8 and supplementary Figure 1). A striking number of probes in this module coded for genes collectively associated with oxidative phosphorylation (OXPHOS), including subunits of the respiratory chain and ribosomal subunits required for translation of respiratory chain subunits (KEGG pathways Oxidative Phosphorylation, $p=3.9 \times 10^{-5}$; Ribosome, $p=6.6 \times 10^{-5}$; and Alzheimer's disease, $p=1.8 \times 10^{-4}$, supplementary Figure 1 and supplementary Table 10). Genes attributable to the KEGG ribosome pathway were also enriched in the red (ribosome/translation) module $\left(p=1.7 \times 10^{-7}\right)$.

Following further analysis of the 77 genes assayed which form part of the mitochondrial respiratory chain (complex I to V) (OXPHOS), 32 were found to be significantly dysregulated in MCI and/or AD compared to control blood, with all but 3 genes showing decreased expression in disease (supplementary Table 8). Additionally, subunits of the mitochondrial ribosome expressed from the nuclear genome (MRP genes) and involved in translation of proteins for the respiratory chain complex from the mitochondrial genome, and/or ribosomal subunit genes involved in nuclear gene translation, were down-regulated in disease. Of the $78 \mathrm{MRP}$ genes assayed, 28 had lower expression in MCI and/or AD compared to controls (supplementary Table 8 and supplementary Figure 1).

GO analysis also revealed a significant overrepresentation of immune-related genes in the blue (immune) module with the most significant trait and module-associated genes enriched in the Leukocyte transendothelial migration KEGG pathway, $p=1.2 \times 10^{-4}$ (supplementary Tables 6 and 8 and supplementary Figure 1). Immune related genes were generally found in the blue (immune) and turquoise (transcription) modules, displaying modest upregulation of their expression in MCI and/or AD blood.
Most notable were genes which encode key adhesion molecules within the selectin (L-, P-, and E-selectin, P-selectin glycoprotein ligand 1), immunoglobulin superfamily (ICAMs, VCAM, and madCAM), integrin (CD11/CD18 and $\alpha-4)$ and chemokine gene families, which are crucial for leukocyte slowing, rolling and tethering in response to activated endothelial cell signals in blood microvessels (Fig. 5 and supplementary Tables 1-8). Both subunits of the LFA1 (CD11a/CD18, ITGAL/ITGB2, $\alpha \mathrm{L} \beta 2)$ and Mac-1 (CD11b/CD18, ITGAM/ITGB2, $\alpha \mathrm{M} \beta 2$ ) [91] complexes were upregulated. There were also changes in the genes encoding their downstream effectors such as Fyn and FGR. The cell-cell and extracellular matrix adhesion genes ITGAX and ITGB7 were upregulated while $C L D N D 1$, a gene with adhesion properties important for maintaining tight junction integrity and regulating cell polarity was down-regulated. Members of the ADAM family of type I transmembrane glycoproteins, $A D A M 8$, and $A D A M 10$, were also upregulated. These are known to be involved in cell adhesion and processing of cytokines and adhesion molecules [92]. In particular, ADAM 8 has been shown to cleave L-selectin from the plasma membrane of activated neutrophils, and through this activity is predicted to facilitate transendothelial extravasation [93]. It is also possible that upregulation of ADAM genes may increase shedding of L-selectin to prevent rather than increase cell adhesion and resolve inflammation, as has been found for ADAM17 [94].

Other noteworthy genes altered in the blood of MCI and/or AD people which might promote transendothelial extravasation of leukocytes include progranulin $(G R N)$. The increase in expression of progranulin in blood from people with MCI is consistent with previous findings [95]. Progranulin can stimulate neutrophil and macrophage infiltration and neovascularization of wound tissue $[96,97]$ or alternatively display anti-inflammatory activity as an antagonist to TNF/TNFR signaling [98]. The expression of a number of pattern recognition receptors important for sensing a pathogenic or sterile stimulus [99], were either upregulated as in the case of three NLR family members (NLRP1, NLRP12, and NLRC5) and C-type lectin domain receptors (CLEC16A) or down-regulated (CLEC4D, CLEC4A, and CLEC7A and AIM2), in MCI and/or AD subjects. Interestingly, TLR2 and TLR8, which are part of the toll-like receptor family of pattern recognition receptors, were not altered in MCI subjects but were significantly upregulated in $\mathrm{AD}$ patients, along with upregulation of FGR which mediates TLR protein signals in addition to those of the LFA-1 and 


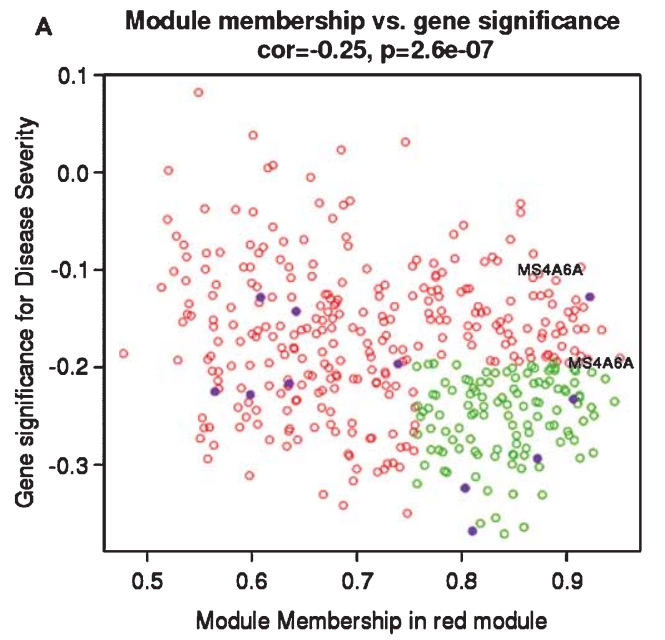

C Module membership vs. gene significance
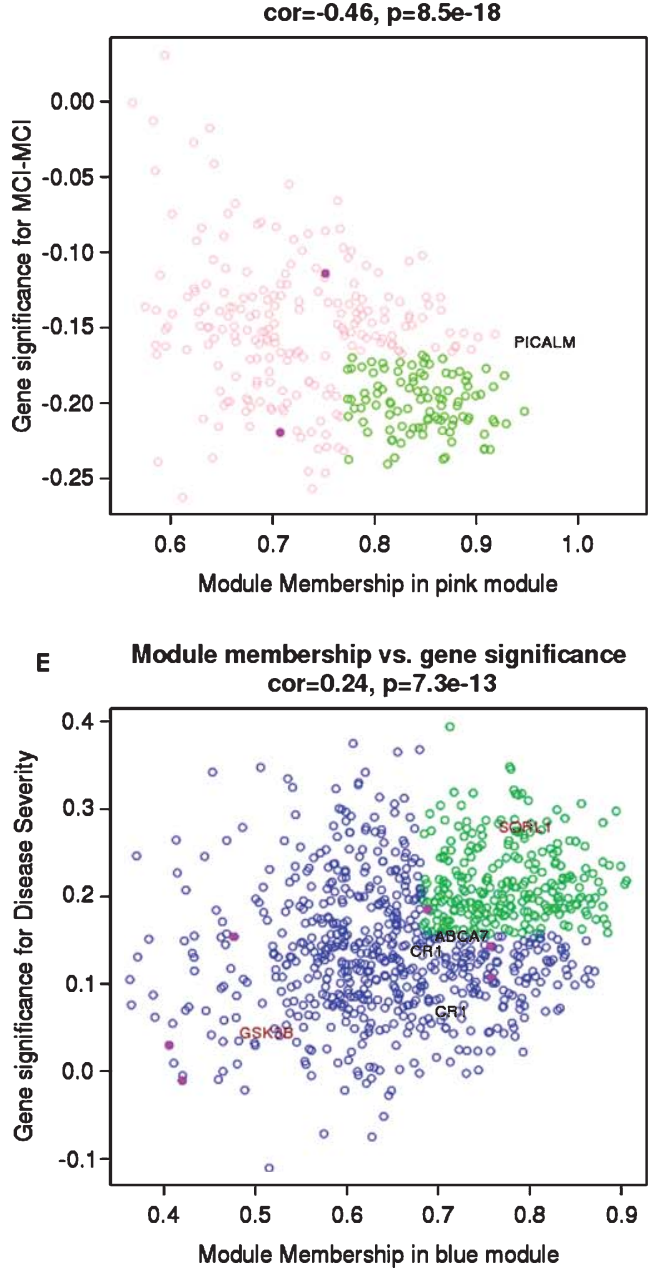

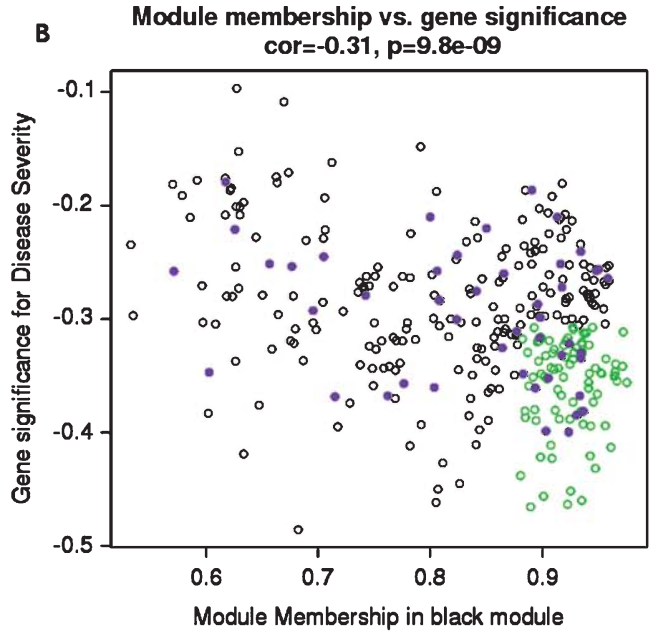

D Module membership vs. gene significance

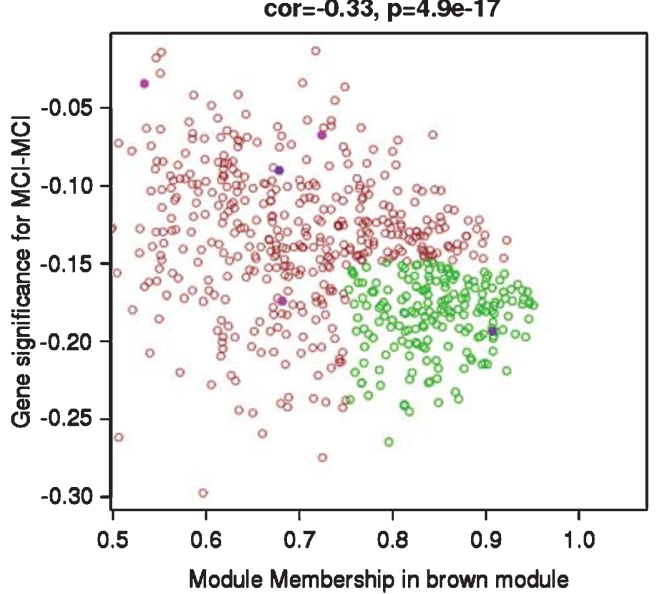

F Module membership vs. gene significance

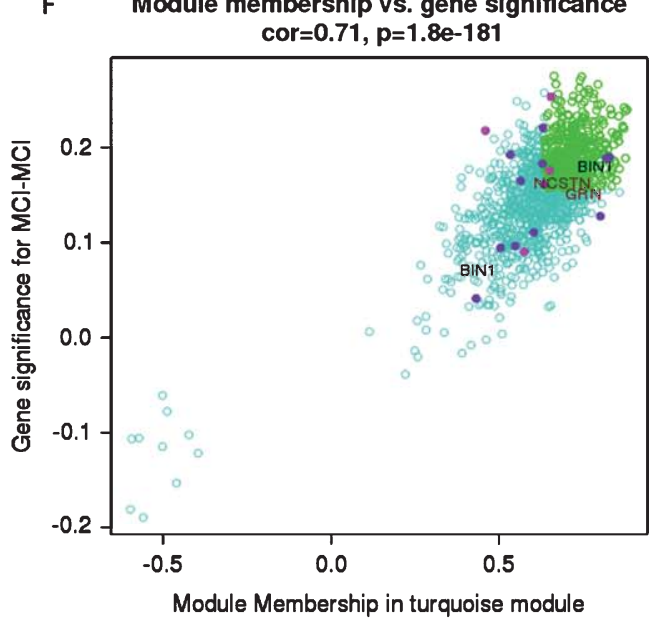

Fig. 5. (continued) 
Mac-1 complexes. Some of these genes not only had a strong disease association but also had expression patterns characteristic of the modules in which they were allocated (Fig. 5).

Of the candidate disease genes analyzed, only SORL1 (blue-immune module) and BINI (turquoisetranscription module) had higher-than-median module membership and trait significance, suggesting they may have significant influence over the behavior of other genes in their respective modules (Fig. 5). Other candidate genes including the disease associated genes NCSTN and GRN (turquoise-transcription module) and GSK3B (blue-immune module) and the AD susceptibility genes CRI (blue-immune module), ABCA7 (blue-immune module), PICALM (pink-secretory/endocytosis module), and MS4A6A (red-ribosome/translation module) while assigned to modules either did not appear to be central to the characteristics of the module and/or did not display significant alteration in expression in disease.

\section{Changes in blood cell number are unlikely to explain the disease associated gene expression differences observed in MCI and AD blood}

Blood is a heterogeneous and dynamic tissue containing many different leukocyte populations. Leukocyte cell numbers can differ during disease and inflammation. In light of this, we compared the numbers of circulating leukocytes in blood from $\mathrm{AD}, \mathrm{MCI}$, and normal elderly control subjects to explore whether the gene expression changes we observe might reflect a shift in blood cell number or could potentially be explained by the activity of a particular cell type in blood. Of the three granulocyte populations investigated, only the number of basophils, a minor cell type in blood, was significantly different between control and disease blood samples. There were more basophils in blood from MCI and AD subjects compared to controls (Fig. 6A; Bonferonni-corrected $p<0.017$ ). The numbers of neutrophils, eosinophils, and lymphocytes (Fig. 6B-D) were similar between diagnostic groups, while the numbers of monocytes, a particularly active cell, were significantly lower in blood from MCI subjects compared to AD (Fig. 6E; Bonferonni-corrected $p<0.017)$. All subjects included in the analysis had blood cell numbers considered to be within the normal acceptable range for each cell type, indicating the changes we observed were small and not indicative of serious illness.

None of the leukocyte populations investigated had greater numbers of differentially regulated genes than any other cell type, given the total number of dysregulated between control, MCI and AD and the numbers of genes analyzed (supplementary Table 9). There were in fact fewer dysregulated genes representing activated granulocytes in MCI and B cells in AD than might be expected, suggesting activity in these cells was unlikely to explain a significant proportion of the gene expression differences we observed in disease (supplementary Table 9). Overall, our data suggests no one cell type is likely to be driving the gene expression changes we observe in disease and that the diseaserelated changes we report are not a simple reflection of a shift in cell numbers in disease.

\section{Blood and brain module preservation}

There was significant concordance between blood modules and brain-related modules generated from multiple published expression and protein datasets generated from brain tissue (supplementary Table 10). For example, the black (ribosome/mitochondria) module was significantly enriched with genes from brain modules, displaying a similar direction of change of expression in disease and preservation of module characteristics across datasets and species (supplementary Table 10). To explore this further, we investigated two well-powered studies of gene expression generated from hippocampus [77] and cortical regions [87] from control and AD patients. The black (ribosome/mitochondria) module showed high density preservation but was less preserved with respect to connectivity (Fig. 7), indicating a possible change in roles for the hub genes in the brain, although it should be noted that the two brain datasets alone did not

Fig. 5. The correlation between module membership (MM) and gene significance (GS) for each probe was computed. Scatterplots for the most significant traits and modules are presented, illustrating the relationship between MM and GS at the probe level and indicating how central a given probe is to each module and how associated it is with the traits we examined of disease severity (A, B, and E) or MCI relative to control (MCI-MCI) (C, D, and F). The following six modules were used for correlation: Red (ribosome/translation) (A), Black (ribosome/mitochondria) (B), Pink (secretory/endocytosis) (C), Brown (metabolic) (D), Blue (immune) (E), and Turquoise (transcription) (F). Probes highlighted in green exhibited higher-than-median module membership and trait significance, so are likely to be core module probes. Probes encoding mitochondrial protein subunits of complex I to $\mathrm{V}$ of the respiratory chain and protein subunits of the mitochondrial ribosome (listed in supplementary Table 8 ) are colored in purple, while probes encoding important immune-associated genes (listed in supplementary Table 8) are colored in dark pink. Candidate genes, which are listed in supplementary Table 8, are highlighted by gene name. 


\section{A}

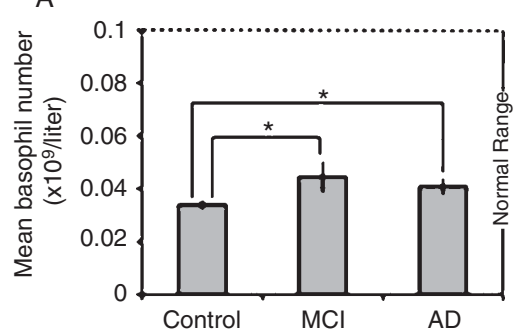

D

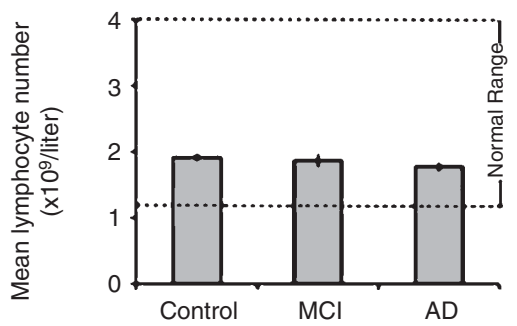

$\mathrm{B}$

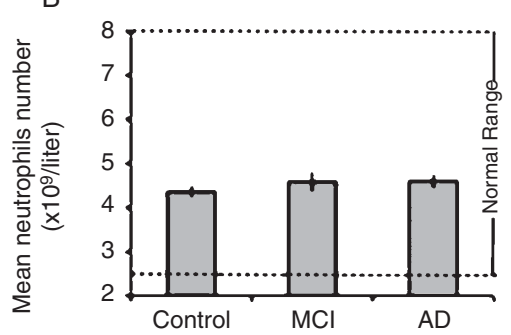

$\mathrm{E}$

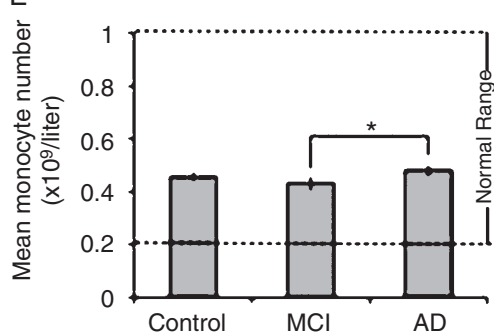

C
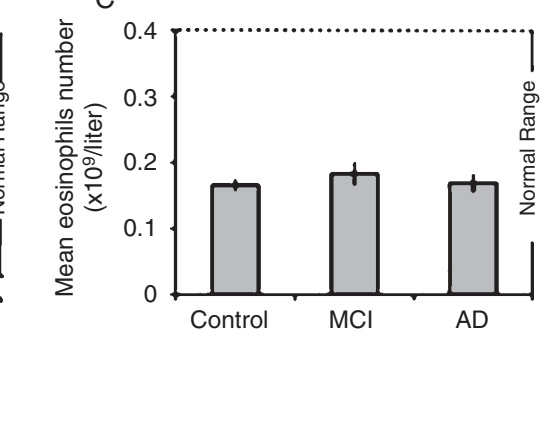

Fig. 6. A Full Blood Count analysis was undertaken to compare the numbers of various leukocyte populations in blood from AD, MCI, and normal elderly subjects. Three granulocyte populations were examined: basophils (A), neutrophils (B), and eosinophils (C) and two peripheral blood mononuclear populations, lymphocytes (D) and monocytes (E). Data within the normal range ( $\pm 10 \%)$ was included in the analysis. Graphs represent mean leukocyte number $\left(\times 10^{9} /\right.$ liter $) \pm$ SEM in normal elderly controls $(n=125)$, MCI $(n=41)$, and AD subjects $(n=73)$. Following $\log _{10}$ transformation of the data, linear regression was carried out to assess the effect of disease status on individual leukocyte populations, adjusting for age, gender, and other blood cell types. *Significance, Bonferonni-corrected $p<0.017$.

show particularly high connectivity concordance with each other (data not shown). In the hippocampus, the black (ribosome/mitochondria) module had Z-density and Z-summary $>10$ (threshold for high preservation) which was the highest among all the modules and had the highest median rank density statistics. In cortical tissue, the black (ribosome/mitochondria) module maintained Z-density $>10$ and ranked second highest with respect to median rank and median rank density. This pattern did not appear in the Z-connectivity and median rank connectivity statistics. Another module which showed some preservation across both data sets was the brown (metabolic) module. Again, the preservation patterns were stronger in the hippocampus than in cortical tissue. Connectivity of the brown (metabolic) module was more preserved than the black (ribosome/mitochondria) module. The red (ribosome/translation) module was only preserved in the hippocampal brain data, while the pink (secretory/endocytosis) module, which was associated with changes in MCI subjects only, showed only weak preservation in both brain datasets. Finally, the turquoise (transcription) and blue (immune) modules appeared to be unpreserved in the hippocampus, but at least for the turquoise (transcription) module, more highly preserved in cortical tissue than in the hippocampus.

\section{DISCUSSION}

We have identified a large number of differentially expressed genes in blood samples from MCI and AD subjects compared to normal controls using microarray technology. These dynamic changes could be grouped in to six disease-associated co-expression modules each containing genes with characteristic biological identities. There were strong associations in the red module with lower ribosomal function and translation, the black module with decreased mitochondrial function and translation, the pink module with lower secretory and endocytic function, the brown module with decreased metabolic processes, the blue module with altered immune function and the turquoise module with promotion of transcription in disease.

Disease was most strongly associated with lower expression of genes encoding respiratory chain subunits or ribosomal protein subunits which translate respiratory subunit genes from the mitochondrial genome. These genes were predominantly allocated to 

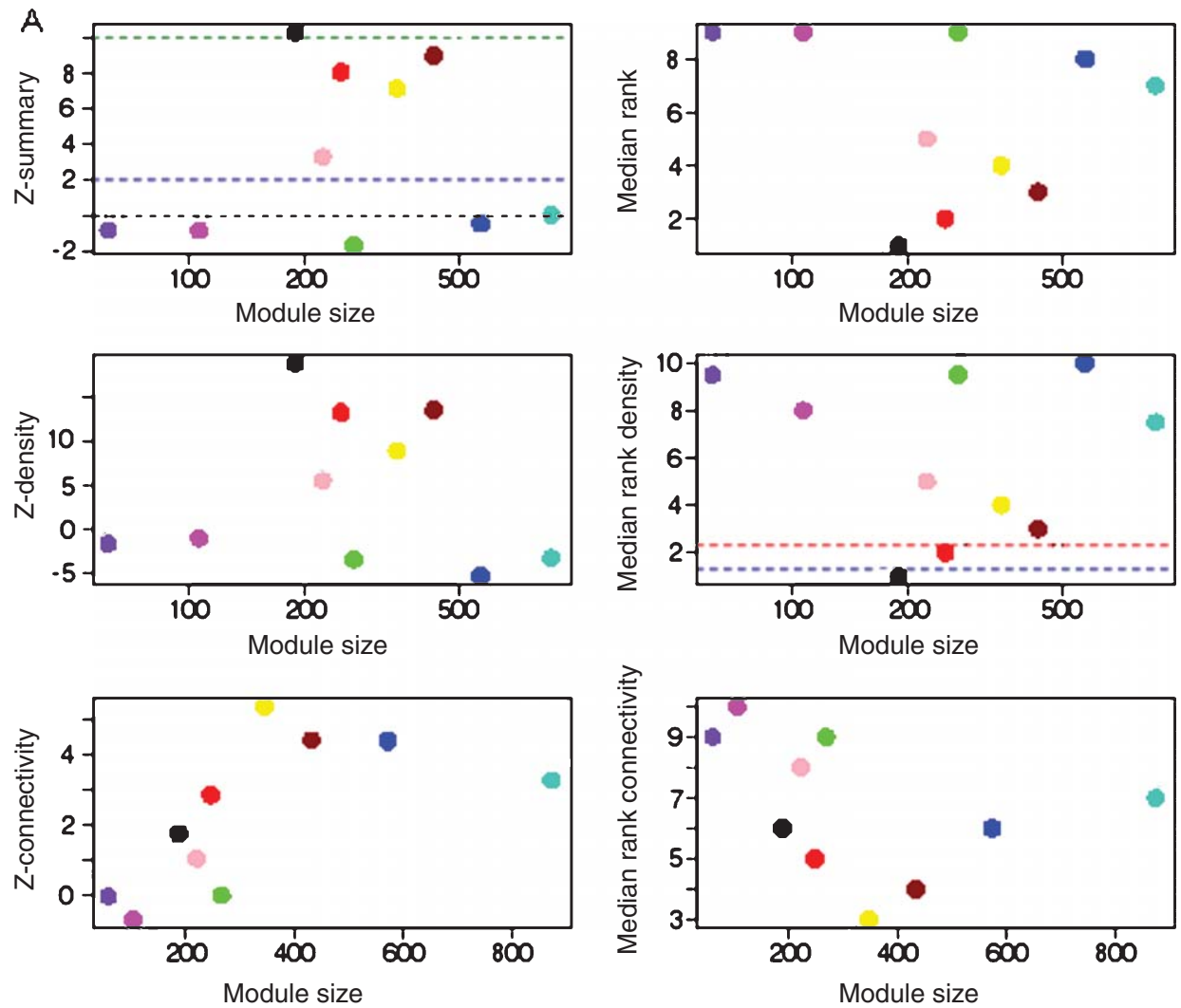

Fig. 7. The blood module preservation results across the two publically available AD human brain gene expression data sets (Liang (A) and (B) Myers [77, 87]). The scatter plots describe the relation between the different modules and the six module-preservation statistics. For each plot, the $\mathrm{x}$-axis corresponds to the module size while the $\mathrm{y}$-axis is the value of the preservation statistics in question. Each plot contains the ten modules represented by their colors. The dotted lines represent the nominal strength of the relationship: the higher the value of a Z-statistic, the stronger the evidence that the module displays significantly higher preservation than expected by chance for Z-summary, Z-density, and median rank intensity.

the black (ribosome/mitochondria) module and were present in both AD patients and MCI subjects, including those known to have prodromal AD (MCI-AD). The production of ATP and respiratory chain activity therefore appears to be compromised early in disease.

\section{Mitochondrial (respiratory chain) dysfunction is a consistent hallmark of $A D$}

Platelets and lymphocytes have previously been found to have significantly reduced respiratory chain activity in MCI and AD subjects [16, 22-24]. In agreement with our findings, several studies have shown decreased cytochrome c activity (complex IV) in human platelets from AD patients [22, 100, 101] and lower abundance of complex IV proteins in blood from people with MCI [24]. Remarkably, the changes we observe in the respiratory chain in AD blood are also well-preserved in brain in terms of density of the black module, particularly in the hippocampus $[15,77,102]$, suggesting a shared disease response between these two tissues. Down-regulation of respiratory chain subunits and genes that regulate their transport in to the mitochondrion have been previously described in $\mathrm{AD}$ in a number of brain regions at both the RNA and protein levels [103]. Alterations to the OXPHOS/respiratory chain may in part provide an explanation for the significantly reduced glucose metabolism measured by FDG-PET which manifests very early in disease [104]. The overlap between blood and brain may represent a common response to the same disease-associated signal(s). A direct and indirect link between toxic $A \beta$ species and respiratory chain activity has been well described in AD brain tissue [105], and it is plausible that the changes in circulating levels of $A \beta$ in plasma [106] or the increase in $A \beta$ 

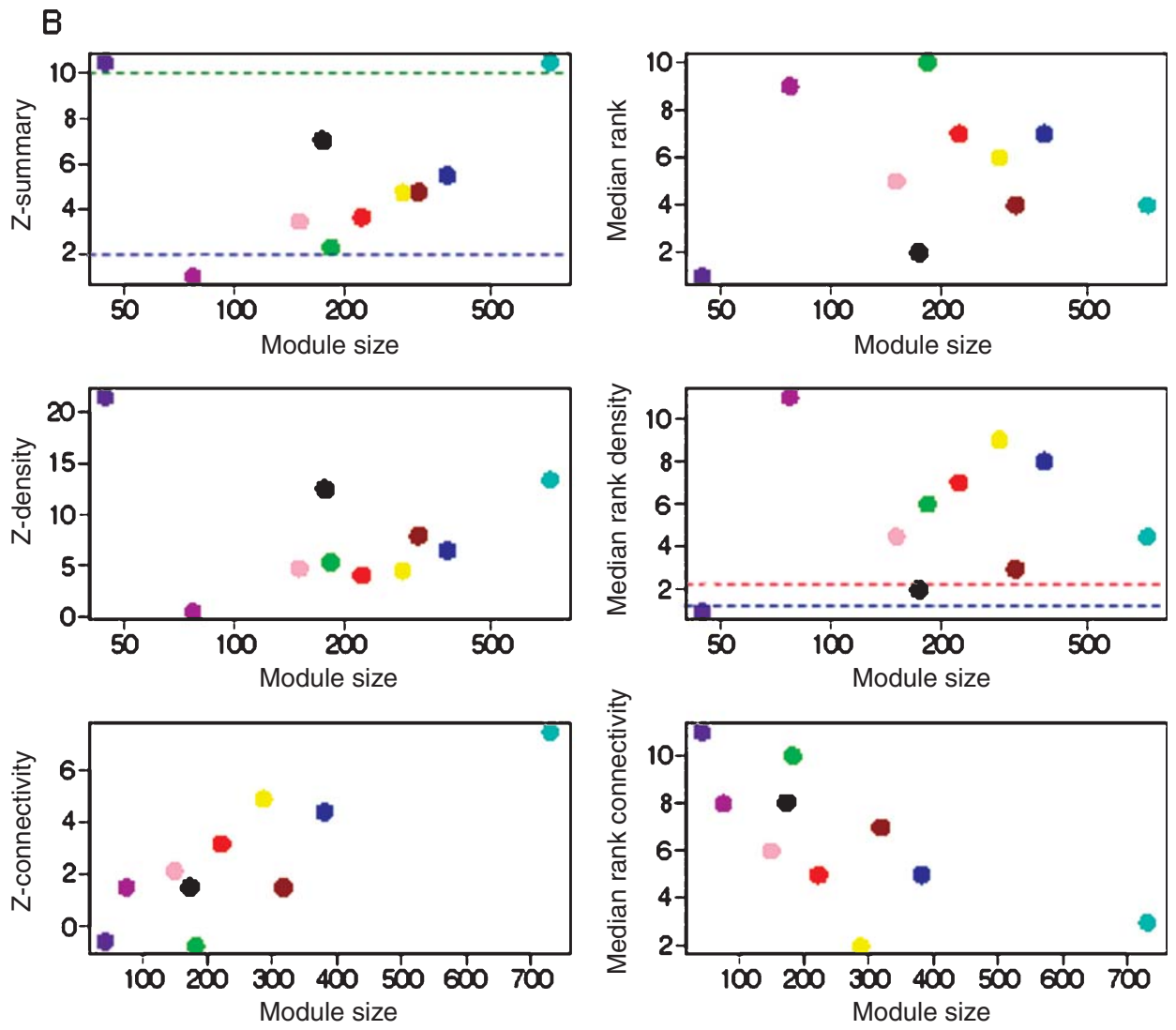

Fig. 7. (continued)

associated with blood vessels could provide the signal to blood cells in the periphery, resulting in the same genes being affected. Other more indirect signals may also be responsible.

Inherited mutations in respiratory chain subunits and assembly genes which we find down-regulated in the current study, including NDUSF4 [107], NSUSF3 [108], NDUFA1 [109, 110], UQCRB [111], UQCRQ [112], and MRPS22 [113, 114], can cause loss of activity in complexes I, II, III, IV, and/or V and give rise to complex disease phenotypes which include Leigh syndrome, Leigh-like syndrome, fatal infantile lactic acidosis, neonatal cardiomyopathy with lactic acidosis, macrocephaly with progressive leukodystrophy, and unspecific encephalomyopathy [115]. Of particular relevance to the current study is the frequent occurrence of neurodegeneration in such diseases. The respiratory chain operates as a supercomplex involving complex interactions involving around 100 proteins derived from the nuclear and mitochondrial genomes, assembled in to five complexes. Each complex involves variable assemblies of components to enable precise and dynamic control of thermodynamic and kinetic properties and thereby the modulation of functions including ATP generation [116]. It is difficult to predict with accuracy how a change in abundance of an individual protein subunit would affect the respiratory chain beyond the individual complex in which the affected subunit is located.

Nevertheless, compromised respiratory chain activity is expected to affect ATP production and increase cellular stress and generate excessive production of mitochondrial reactive oxygen species (mROS) which can damages cell components and lead to cell death. Mitochondria generate a significant amount of ROS when the respiratory chain, particularly complexes I and III, are compromised [117, 118]. mROS is believed to be one of the main events contributing to neuronal cell loss in $\mathrm{AD}$ and other related neurodegenerative disorders [119, 120]. Consistent with our findings, freshly isolated platelets [22] and lymphocytes [121, 122] from AD patients have decreased ATP levels, increased levels of ROS, and increased expression of genes associated with oxidative stress [18, 21], and 
there is evidence of oxidative damage to plasma proteins, occurring even in mild disease [123]. Leukocytes are also more susceptible to respiratory chain inhibitors [121, 124-126] and have elevated DNA fragmentation and spontaneous apoptotic cell death [127-130]. Apoptosis of leukocytes in tissues is normally a critical mechanism for rapidly resolving inflammation and avoiding collateral inflammatory tissue damage by activated cells [131, 132]. We did not observe changes in genes encoding apoptotic markers in our samples, although activation of many of these genes is more likely to occur post-translationally and therefore would not be observed in our study. It will be important to establish if the changes we see lead to increased blood cell apoptosis in patients with MCI or AD and their increased clearance from circulation.

While excessive ROS can be detrimental, mROS is also an important intermediate signal for normal cell function. In the immune system, it can mediate signaling pathways including the RLR-dependent antiviral responses [133] and the TLR-dependent response [134], both of which signal through the NF- $-\mathrm{B}$, MAPK [135], ERR $\alpha-P G C 1 \beta$ [136], and/or NLRP3 inflammasome [137] pathways to generate an immune response. mROS can enhance pro-inflammatory cytokine production and stimulate the oxidative burst in activated cells. The increase in activation markers we observe could therefore herald a healthy innate immune response characterized by increased leukocyte adhesion to the endothelium [138] and mobilization of these cells to the site of tissue injury. It will be important to establish whether the changes we find in mitochondrial genes are sufficient to increase mROS and support a healthy pro-inflammatory environment or alternatively, lead to excessive mROS production and a reduction in chemotactic behavior, oxidative burst, reduction in glycolysis, and cell clearance through apoptosis to prevent further immune activity [139, 140].

\section{Immune activation is a prominent feature of $A D$}

Our data support the presence of a chronic low grade innate immune response in people with $\mathrm{MCI}$ and $\mathrm{AD}$. Important signaling, cell adhesion, and motility gene markers were upregulated, consistent with leukocytes having an activated phenotype, which is expected to increase endothelial cell association, leukocyte rolling, and transendothelial extravasation (diapedesis). These genes are predicted to be blood specific, so it is no surprise that the blue (immune) module which they mainly belong to was not highly conserved in the brain. Activation of these genes is predicted to have arisen from a sterile immune response initiated in the brain [141] with the changes we observe likely to be part of a sustained and chronic peripheral response. Increased brain-associated inflammatory activity and systemic changes have been extensively described in AD. A $\beta$ and/or dying neuronal cells are thought to trigger a local sterile immune response in $\mathrm{AD}$ brain $[99,142]$. $\mathrm{A} \beta$ can bind to a multitude of receptors expressed on brain microglia, and can elicit the production of proand/or anti-inflammatory mediators such as cytokines and chemokines and ROS, which may exacerbate disease [143-147]. Alongside this cascade of events, alterations in the levels of acute phase proteins, in particular chemokines, pro-inflammatory cytokines [35, 148, 149], endothelial markers [150], and markers of complement activation [33, 151-153] have all consistently been found in blood early in AD and are thought to coincide with endothelial signals which in turn increase leukocyte migration into the brain, perhaps further propagating the inflammatory response [144, 154-157]. Polymorphisms in genes with inflammatory functions have emerged as important pathways which confer disease susceptibility in many GWAS studies [158-164]. Interestingly, variants of the sortilin-related receptor (SORL1) gene (a central hub in the blueimmune module), which was significantly upregulated in the blood of people with MCI, is a susceptibility gene for $\mathrm{AD}$, albeit the increased risk is very small [165]. SORL1 has been shown to functionally interact with $A \beta P P$, preventing homodimer formation which is believed in turn to affect secretase activity and A $\beta P P$ processing, culminating in decreased production of amyloidogenic products [166]. A $\beta$ peptides are abundant in human plasma and have been evaluated as possible biomarkers for AD. A net increase in SORL1 expression, which we found in MCI blood, may in part be responsible for the decrease in $A \beta$ peptides found in plasma from prodromal AD patients [167]. Furthermore, SORL1 expression was lower in AD subjects compared to MCI blood, which coincides with the presence of higher $\mathrm{A} \beta$ peptides in people with $\mathrm{AD}$ [168]. As SORL1 is a multifunctional protein thought to be important in the endocytic pathway, it may have additional roles in disease which could include controlling some of the immune-associated genes co-expressed in the blue (immune) module. It will be particularly interesting to test whether the AD-associated SORL1 variants previously identified are able to exert a transacting influence over the expression of any other genes in the blue (immune) module. 
Despite the presence of immune activation signals and markers of response, it is unclear whether the changes we see in disease represent diapedesis of leukocytes across the blood brain barrier. The degree of differential expression between control and disease blood was less significant for immune-related genes than for other differentially expressed genes. As the cells we sample in venous blood are still circulating they are not expected to have displayed sufficiently strong activation signals to enable them to have crossed the blood brain barrier (BBB). No study has yet reported an increase in the expression of the most important endothelial-specific adhesion molecules (ICAM-1, VCAM-1, and E selectin) at the BBB capillaries in AD, which would be necessary to bind the adhesion proteins we find increased in leukocytes at the RNA level [169]. There are, however, reports of clear disruption of the BBB and changes consistent with activation of endothelial cells and increased permeability, particularly in advanced disease [170-175], which is consistent with the profile we found. In some studies, significant numbers of monocytes [144, 154, 176-178] and T-lymphocytes [157, 179-182] are detectable in AD brain. However, as the mice used in these studies were grafted with GFPexpressing hematopoietic cells following irradiation, cell infiltration into the brain could be attributable to loss of BBB integrity as a consequence of irradiation $[157,183]$. Other studies find very little evidence for significant leukocyte infiltration in the brain in the absence of disease [184]. It will be important to establish whether the activated phenotype we observed in blood cells very early in disease ultimately results in these cells being able to cross the BBB in patients, or merely reflects a priming of this process. Even if these cells do not actually cross the BBB, the markers of chronic activation we observed suggest these cells could be contributing to the pathology observed at the $\mathrm{BBB}$ in $\mathrm{AD}$ perhaps by producing damaging ROS.

Genes assigned to the pink, brown, and turquoise modules (associated with secretory/endocytic pathways, metabolism, and transcription, respectively) were altered in MCI blood, but generally returned to normal levels in $\mathrm{AD}$ patients. These changes may reflect protective or compensatory mechanisms activated when disease first emerges which abate when established clinical symptoms of disease develop. Interestingly, the two AD susceptibility genes PICALM and BIN1 [158, 159, 162-164, 185], both believed to be important proteins involved in endocytic processing $[186,187]$, displayed this type of expression pattern. BIN1 was central to the characteristics of the turquoise (transcription) module displaying significantly greater expression in MCI subjects and lower expression in AD patients. BIN1 may be an important regulator of expression of other transcription-associated genes in the turquoise (transcription) module, which would be consistent with a role previously described for this gene [188].

\section{Changes are likely to be cell autonomous}

None of the individual leukocyte cell populations analyzed had a higher proportion of cell marker genes altered in MCI or AD than any other cell type, despite MCI patients having significantly fewer monocytes than control and AD patients, and MCI and AD patients having higher numbers of basophils. This indicates no preferential activation of any one particular cell type in disease and suggests that our results do not merely reflect a change in the proportion of different cells in blood. Compared to other cells, B lymphocytes had relatively fewer gene expression changes in AD than might be expected by chance, suggesting that this branch of the adaptive immune system may not be activated in $\mathrm{AD}$ [99]. Similar changes in blood cell number have been reported previously [189]. Importantly, our findings suggest that the differentially expressed genes largely represent disease-associated cell autonomous changes and do not merely reflect changes in cell numbers, as there was no clear association between gene expression and individual blood cell populations.

\section{The promise of blood for screening}

The strong concordance between the respiratory changes in AD blood and brain suggests blood might be a good model for testing novel therapies, particularly those that target mitochondrial dysfunction. Neuroprotective strategies to neutralize oxygen radicals or alter respiratory chain activity to prevent oxidative damage in $\mathrm{AD}$ have been strongly pursued with many drugs such as Coenzyme $\mathrm{Q}$ derivatives and Dimebon now being tested in clinical trials. While clearly a relevant target in $\mathrm{AD}$, results of clinical trials targeting mitochondrial dysfunction have thus far been very disappointing. A greater effort to screen promising candidates for disease efficacy in ex vivo blood cultures, or using the markers we have identified as outcome measures in in vivo screening studies, may perhaps improve the identification of promising candidates and provide data to help triage drugs to progress into clinical trials. 


\section{CONCLUSIONS}

Overall, it is possible the weak inflammatory signal we find could be offset by the much stronger changes in respiratory chain activity which may be expected to lead to blood cell clearance from circulation to prevent collateral tissue damage. Our results are particularly exciting as they demonstrate mitochondrial and inflammatory changes in the periphery occur very early in $\mathrm{AD}$, some of which are also known mechanisms occurring in $\mathrm{AD}$ brain. Fundamentally, these could be used as the basis for identifying people early in disease and for monitoring the efficacy of novel therapeutics for a range of disorders characterized by mitochondrial dysfunction in the CNS and blood. Resolving inflammation and preventing oxidative damage are very active areas being explored as possible targets for drug development in $\mathrm{AD}$ and our findings suggest blood could be a very good model in which to evaluate their efficacy.

\section{ACKNOWLEDGMENTS}

We thank Rufina Leung, Megan Pritchard, Belinda Martin, Kathryn Lord, Nicola Dunlop, and Catherine Tunnard for sample collection and neuropsychiatric assessments at the London site. We also thank all the research participants for their generous involvement in this research. This work was supported by InnoMed, (Innovative Medicines in Europe) an Integrated Project funded by the European Union of the Sixth Framework program priority FP6-2004-LIFESCIHEALTH-5, the Alzheimer's Research Trust, The John and Lucille van Geest Foundation and the NIHR Biomedical Research Centre for Mental Health at the South London and Maudsley NHS Foundation Trust and [Institute of Psychiatry] Kings College London.

Authors' disclosures available online (http://www.jalz.com/disclosures/view.php?id=1201).

\section{REFERENCES}

[1] Albanese E, Banerjee S, Dhanasiri S, Fernandez J, Ferri C, Knapp M, McCrone P, Prince M, Snell T, Stewart R Dementia UK (2007), A report into the prevalence and cost of dementia, http://www.psige.org/psigepdfs/Dementia_UK_Summary.pdf.

[2] Mckhann G, Drachman D, Folstein M, Katzman R, Price D, Stadlan EM (1984) Clinical-diagnosis of Alzheimersdisease - Report of the nincds-adrda work group under the auspices of department-of-health-and-human-services taskforce on Alzheimers-disease. Neurology 34, 939-944.

[3] de Jager CA, Honey TEM, Birks J, Wilcock GK (2010) Retrospective evaluation of revised criteria for the diagnosis of Alzheimer's disease using a cohort with post-mortem diagnosis. Int J Geriat Psychiatry 25, 988-997.

[4] Kazee AM, Eskin TA, Lapham LW, Gabriel KR, Mcdaniel KD, Hamill RW (1993) Clinicopathological correlates in Alzheimer-disease - Assessment of clinical and pathological diagnostic-criteria. Alzheimer Dis Assoc Disord 7, 152-164.

[5] Petrovitch H, White LR, Ross GW, Steinhorn SC, Li CY, Masaki KH, Davis DG, Nelson J, Hardman J, Curb JD, Blanchette PL, Launer LJ, Yano K, Markesbery WR (2001) Accuracy of clinical criteria for AD in the Honolulu-Asia Aging Study, a population-based study. Neurology 57, 226234.

[6] Varma AR, Snowden JS, Lloyd JJ, Talbot PR, Mann DMA, Neary D (1999) Evaluation of the NINCDS-ADRDA criteria in the differentiation of Alzheimer's disease and frontotemporal dementia. J Neurol Neurosurg Psychiatry 66, 184-188.

[7] Hardy J (1997) Amyloid, the presenilins and Alzheimer's disease. Trends Neurosci 20, 154-159.

[8] Jack CR, Knopman DS, Jagust WJ, Shaw LM, Aisen PS, Weiner MW, Petersen RC, Trojanowski JQ (2010) Hypothetical model of dynamic biomarkers of the Alzheimer's pathological cascade. Lancet Neurol 9, 119-128.

[9] Petersen RC (2003) Conceptual overview. In: Mild Cognitive Impairment, Petersen RC, Ed. Oxford University Press, New York, pp. 1-14

[10] Jicha GA, Parisi JE, Dickson DW, Johnson K, Cha R, Ivnik RJ, Tangalos EG, Boeve BF, Knopman DS, Braak $\mathrm{H}$, Petersen RC (2006) Neuropathologic outcome of mild cognitive impairment following progression to clinical dementia. Arch Neurol 63, 674-681.

[11] Cameron B, Landreth GE (2010) Inflammation, microglia, and Alzheimer's disease. Neurobiol Dis 37, 503-509.

[12] Salminen A, Ojala J, Kauppinen A, Kaarniranta K, Suuronen T (2009) Inflammation in Alzheimer's disease: Amyloidbeta oligomers trigger innate immunity defence via pattern recognition receptors. Prog Neurobiol 87, 181-194.

[13] Heneka MT, O’Banion MK (2007) Inflammatory processes in Alzheimer's disease. J Neuroimmunol 184, 69-91.

[14] Ankarcrona M, Mangialasche F, Winblad B (2010) Rethinking Alzheimer's disease therapy: Are mitochondria the key? J Alzheimers Dis 20, S579-S590.

[15] Manczak M, Park BS, Lung YS, Reddy PH (2004) Differential expression of oxidative phosphorylation genes in patients with Alzheimer's disease - Implications for early mitochonrial dysfunction and oxidative damage. Neuromol Med 5, 147-162.

[16] Rhein V, Song XM, Wiesner A, Ittner LM, Baysang G, Meier F, Ozmen L, Bluethmann H, Drose S, Brandt U, Savaskan E, Czech C, Gotz J, Eckert A (2009) Amyloid-beta and tau synergistically impair the oxidative phosphorylation system in triple transgenic Alzheimer's disease mice. Proc Natl Acad Sci U S A 106, 20057-20062.

[17] Manczak M, Anekonda TS, Henson E, Park BS, Quinn J, Reddy PH (2006) Mitochondria are a direct site of A beta accumulation in Alzheimer's disease neurons: Implications for free radical generation and oxidative damage in disease progression. Hum Mol Genet 15, 1437-1449.

[18] Fehlbaum-Beurdeley P, Prado ACJL, Pallares D, Carriere J, Soucaille C, Rouet F, Drouin D, Sol O, Jordan H, Wu DR, Lei L, Einstein R, Schweighoffer F, Bracco L (2010) Toward an Alzheimer's disease diagnosis via high-resolution blood gene expression. Alzheimers Dement 6, 25-38.

[19] Grunblatt E, Bartl J, Zehetmayer S, Ringel TM, Bauer P, Riederer P, Jacob CP (2009) Gene expression as peripheral 
biomarkers for sporadic Alzheimer's disease. J Alzheimers Dis 16, 627-634.

[20] Rye P, Booij B, Grave G, Lindahl T, Kristiansen L, Andersen H, Horndalsveen P, Nygaard H, Naik M, Hoprekstad D, Wetterberg P, Nilsson C, Aarsland D, Sharma P, Lönneborg A (2011) A novel blood test for the early detection of Alzheimer's disease. J Alzheimers Dis 23, 121-129.

[21] Booij B, Lindahl T, Wetterberg P, Skaane N, Sæbø S, Feten G, Rye P, Kristiansen L, Hagen N, Jensen M, Bårdsen K, Winblad B, Sharma P, Lönneborg A (2011) A gene expression pattern in blood for the early detection of Alzheimer's disease. J Alzheimers Dis 23, 109-119.

[22] Cardoso SM, Proenca MT, Santos S, Santana I, Oliveira CR (2004) Cytochrome c oxidase is decreased in Alzheimer's disease platelets. Neurobiol Aging 25, 105-110.

[23] Parker WD, Mahr NJ, Filley CM, Parks JK, Hughes D, Young DA, Cullum CM (1994) Reduced platelet cytochrome-c-oxidase activity in Alzheimer's disease. $\mathrm{Neu}$ rology 44, 1086-1090.

[24] Valla J, Schneider L, Niedzielko T, Coon KD, Caselli R, Sabbaah MN, Ahern GL, Baxter L, Alexander G, Walker DG, Reiman EM (2006) Impaired platelet mitochondrial activity in Alzheimer's disease and mild cognitive impairment. Mitochondrion 6, 323-330.

[25] Lombardi VRM, Garcia M, Rey L, Cacabelos R (1999) Characterization of cytokine production, screening of lymphocyte subset patterns and in vitro apoptosis in healthy and Alzheimer's Disease (AD) individuals. J Neuroimmunol 97, 163-171.

[26] Graff-Radford NR, Crook JE, Lucas J, Boeve BF, Knopman DS, Ivnik RJ, Smith GE, Younkin LH, Petersen RC, Younkin SG (2007) Association of low plasma A beta 42/A beta 40 ratios with increased imminent risk for mild cognitive impairment and Alzheimer disease. Arch Neurol 64, 354-362.

[27] Lambert JC, Schraen-Maschke S, Richard F, Fievet N, Rouaud O, Berr C, Dartigues JF, Tzourio C, Alperovitch A, Buee L, Amouyel P (2009) Association of plasma amyloid beta with risk of dementia The prospective Three-City Study. Neurology 73, 847-853.

[28] Laske C, Sopova K, Gkotsis C, Eschweiler GW, Straten G, Gawaz M, Leyhe T, Stellos K (2010) Amyloid-beta peptides in plasma and cognitive decline after 1 year follow-up in Alzheimer's disease patients. J Alzheimers Dis 21, 12631269.

[29] Lewczuk P, Kornhuber J, Vanmechelen E, Peters O, Heuser I, Maier W, Jessen F, Burger K, Hampel H, Frolich L, Henn F, Falkai P, Ruther E, Jahn H, Luckhaus C, Perneczky R, Schmidtke K, Schroder J, Kessler H, Pantel J, Gertz HJ, Vanderstichele H, De Meyer G, Shapiro F, Wolf S, Bibl M, Wiltfang J (2010) Amyloid beta peptides in plasma in early diagnosis of Alzheimer's disease: A multicenter study with multiplexing. Exp Neurol 223, 366-370.

[30] Avagyan H, Goldenson B, Tse E, Masoumi A, Porter V, Wiedau-Pazos M, Sayre J, Ong R, Mahanian M, Koo P, Bae S, Micic M, Liu PT, Rosenthal MJ, Fiala M (2009) Immune blood biomarkers of Alzheimer disease patients. $J$ Neuroimmunol 210, 67-72.

[31] Fiala M, Mahanian M, Rosenthal M, Mizwicki MT, Tse E, Cho T, Sayre J, Weitzman R, Porter V (2011) MGAT3 mRNA: A biomarker for prognosis and therapy of Alzheimer's disease by vitamin D and curcuminoids. $J$ Alzheimers Dis 25, 135-144.

[32] Guntert A, Campbell J, Saleem M, O'Brien DP, Thompson AJ, Byers HL, Ward MA, Lovestone S (2010) Plasma gelsolin is decreased and correlates with rate of decline in Alzheimer's disease. J Alzheimers Dis 21, 585-596.

[33] Hye A (2006) Proteome-based plasma biomarkers for Alzheimer's disease. Brain 129, 3042-3050.

[34] O'Bryant SE, Xiao G, Barber R, Reisch J, Doody R, Fairchild T, Adams P, Waring S, az-Arrastia R (2010) A serum protein-based algorithm for the detection of Alzheimer disease. Arch Neurol 67, 1077-1081.

[35] Ray S (2007) Classification and prediction of clinical Alzheimer's diagnosis based on plasma signaling proteins. Nature Med 13, 1359-1362.

[36] Soares HD, Chen Y, Sabbagh M, Rohrer A, Schrijvers E, Breteler M (2009) Identifying early markers of Alzheimer's disease using quantitative multiplex proteomic immunoassay panels. Ann N Y Acad Sci 1180, 56-67.

[37] Thambisetty M, Simmons A, Velayudhan L, Hye A, Campbell J, Zhang Y, Wahlund L, Estman E, Kinsey A, Guentert A, Proitsi P, Causevic M, Killick R, Lunnon K, Lynham S, Broadstock M, Choudhry F, Howlett D, Williams R, Sharp S, Mitchelmore C, Tunnard C, Leung R, Foy C, O'Brien D, Breen G, Furney S, Kloszewska I, Mecocci P, Soinenen M, Tsolaki B, Vellas B, Hodges A, Murphy D, Parkins S, Richardson J, Ferucci L, Wong D, Zhou Y, Muehlboeck S, Evans A, Francis P, Spenger C, Lovestone S (2010) Clusterin, an amyloid chaperone protein in plasma, is associated with severity, pathology and progression in Alzheimer's disease. Arch Gen Psychiatry 67, 739-748.

[38] Thambisetty M, Hye A, Foy C, Daly E, Glover A, Cooper A, Simmons A, Murphy D, Lovestone S (2008) Proteomebased identification of plasma proteins associated with hippocampal metabolism in early Alzheimer's disease. $J$ Neurol 255, 1712-1720.

[39] Lovestone S, Francis P, Strandgaard K, AddNeuroMed CG (2007) Biomarkers for disease modification trials - The innovative medicines initiative and AddNeuroMed. $J$ Nutr Health Aging 11, 359-361.

[40] Lovestone S, Francis P, Kloszewska I, Mecocci P, Simmons A, Soininen H, Spenger C, Tsolaki M, Vellas B, Wahlund L, Ward M, AddNeuroMed, Consortium (2009) AddNeuroMed-The European collaboration for the discovery of novel biomarkers for Alzheimer's disease. Ann NY Acad Sci 1180, 36-46.

[41] Lovestone S, Thambisetty M (2009) Biomarkers for Alzheimer's disease trials - biomarkers for what? A discussion paper. J Nutr Health Aging 13, 334-336.

[42] Simmons A, Westrnan E, Muehlboeck S, Mecocci P, Vellas B, Tsolaki M, Kloszewska I, Wahlund LO, Soininen H, Lovestone S, Evans A, Spenger C, AddNeuroMed Consortium (2009) MRI measures of Alzheimer's disease and the AddNeuroMed Study. Ann N Y Acad Sci 1180, 47-55.

[43] American Psychiatric Association (2000) Diagnostic and statistical manual of mental disorders (IV-TR). 4th edition, text revised.

[44] Petersen RC, Smith GE, Waring SC, Ivnik RJ, Tangalos EG, Kokmen E (1999) Mild cognitive impairment: Clinical characterization and outcome. Arch Neurol 56, 303-308.

[45] Petersen RC, Doody R, Kurz A, Mohs RC, Morris JC, Rabins PV, Ritchie K, Rossor M, Thal L, Winblad B (2001) Current concepts in mild cognitive impairment. Arch Neurol 58, 1985-1992.

[46] Morris JC (1993) The Clinical Dementia Rating (CDR): Current version and scoring rules. Neurology 43, 2412-2414.

[47] Folstein MF, Folstein SE, Mchugh PR (1975) Mini-Mental State - practical method for grading cognitive state of patients for clinician. J Psychiatric Res 12, 189-198. 
[48] Reisberg B, Ferris SH, Deleon MJ, Crook T (1988) Global Deterioration Scale (GDS). Psychopharmacol Bull 24, 661663.

[49] Rosen WG, Mohs RC, Davis KL (1984) A new rating-scale for Alzheimer's disease. Am J Psychiatry 141, 1356-1364.

[50] Cummings JL, Mega M, Gray K, Rosenbergthompson S, Carusi DA, Gornbein J (1994) The neuropsychiatric inventory - aomprehensive assessment of psychopathology in dementia. Neurology 44, 2308-2314.

[51] Galasko D, Bennett D, Sano M, Ernesto C, Thomas R, Grundman M, Ferris S (1997) An inventory to assess activities of daily living for clinical trials in Alzheimer's disease. Alzheimer Dis Assoc Disord 11, S33-S39.

[52] Welsh K, Butters N, Hughes J, Mohs R, Heyman A (1991) Detection of abnormal memory decline in mild cases of Alzheimer's disease using CERAD neuropsychological measures. Arch Neurol 48, 278-281.

[53] Yesavage JA, Brink TL, Rose TL, Lum O, Huang V, Adey M, Leirer VO (1983) Development and validation of a geriatric depression screening scale - a preliminary-report. $J$ Psychiatric Res 17, 37-49.

[54] Du P, Kibbe WA, Lin SM (2008) Lumi: A pipeline for processing Illumina microarray. Bioinformatics 24, 15471548.

[55] Smyth GK (2004) Linear models and empirical bayes methods for assessing differential expression in microarray experiments. Stat Appl Genet Mol Biol 3, Article 3.

[56] Benjamini Y, Hochberg Y (1995) Controlling the false discovery rate - a practical and powerful approach to multiple testing. J Royal Stat Soc Ser B Methodol 57, 289-300.

[57] Zhang B, Horvath S (2005) A general framework for weighted gene co-expression network analysis. Stat Appl Genet Mol Biol 4, Article 17.

[58] Langfelder P, Horvath S (2008) WGCNA: An R package for weighted gene co-expression network analysis. BMC Bioinformatics 9, 559.

[59] Ward JH (1963) Hierarchical grouping to optimize an objective function. J Am Stat Assoc 58, 236.

[60] Simmons A, Westman E, Muehlboeck S, Mecocci P, Vellas B, Tsolaki M, Kłoszewska I, Wahlund LO, Soininen H, Lovestone S, Evans A, Spenger C (2011) The AddNeuroMed framework for multi-centre MRI assessment of Alzheimer's disease: Experience from the first 24 months. Int J Geriat Psychiatry 26, 75-82.

[61] Westman E, Simmons A, Zhang Y, Muehlboeck JS, Tunnard C, Liu Y, Collins L, Evans A, Mecocci P, Vellas B, Tsolaki M, Kloszewska I, Soininen H, Lovestone S, Spenger C, Wahlund LO (2011) Multivariate analysis of MRI data for Alzheimer's disease, mild cognitive impairment and healthy controls. Neuroimage 54, 1178-1187.

[62] Westman E, Simmons A, Muehlboeck JS, Mecocci P, Vellas B, Tsolaki M, Kloszewska I, Soininen H, Weiner MW, Lovestone S, Spenger C, Wahlund LO (2011) AddNeuroMed and ADNI: Similar patterns of Alzheimer's atrophy and automated MRI classification accuracy in Europe and North America. Neuroimage 58, 818-828.

[63] Huang DW, Sherman BT, Lempicki RA (2009) Systematic and integrative analysis of large gene lists using DAVID bioinformatics resources. Nat Protoc 4, 44-57.

[64] Bertram L, McQueen MB, Mullin K, Blacker D, Tanzi RE (2007) Systematic meta-analyses of Alzheimer disease genetic association studies: The AlzGene database. Nat Genet 39, 17-23.

[65] Albright AV, Gonzalez-Scarano F (2004) Microarray analysis of activated mixed glial (microglia) and monocyte- derived macrophage gene expression. J Neuroimmunol 157, 27-38.

[66] Bachoo RM, Kim RS, Ligon KL, Maher EA, Brennan C, Billings N, Chan S, Li C, Rowitch DH, Wong WH, DePinho RA (2004) Molecular diversity of astrocytes with implications for neurological disorders. Proc Natl Acad Sci U S A 101, 8384-8389.

[67] Blalock EM, Geddes JW, Chen KC, Porter NM, Markesbery WR, Landfield PW (2004) Incipient Alzheimer's disease: Microarray correlation analyses reveal major transcriptional and tumor suppressor responses. Proc Natl Acad Sci U S A 101, 2173-2178.

[68] Bult CJ, Eppig JT, Kadin JA, Richardson JE, Blake JA (2008) The Mouse Genome Database (MGD): Mouse biology and model systems. Nucl Acids Res 36, D724-D728.

[69] Cahoy JD, Emery B, Kaushal A, Foo LC, Zamanian JL, Christopherson KS, Xing Y, Lubischer JL, Krieg PA, Krupenko SA, Thompson WJ, Barres BA (2008) A transcriptome database for astrocytes, neurons, and oligodendrocytes: A new resource for understanding brain development and function. J Neurosci 28, 264-278.

[70] Colangelo V, Schurr J, Ball MJ, Pelaez RP, Bazan NG, Lukiw WJ (2002) Gene expression profiling of 12633 genes in Alzheimer hippocampal CA1: Transcription and neurotrophic factor down-regulation and up-regulation of apoptotic and pro-inflammatory signaling. J Neurosci Res 70, 462-473.

[71] Foster LJ, de Hoog CL, Zhang YL, Zhang Y, Xie XH, Mootha VK, Mann M (2006) A mammalian organelle map by protein correlation profiling. Cell 125, 187-199.

[72] Gan L, Ye SM, Chu A, Anton K, Yi SL, Vincent VA, von Schack D, Chin D, Murray J, Lohr S, Patthy L, GonzalezZulueta M, Nikolich K, Urfer R (2004) Identification of cathepsin $\mathrm{B}$ as a mediator of neuronal death induced by $\mathrm{A}$ beta-activated microglial cells using a functional genomics approach. J Biol Chem 279, 5565-5572.

[73] Ginsberg SD, Che SL (2005) Expression profile analysis within the human hippocampus: Comparison of CA1 and CA3 pyramidal neurons. J Comp Neurol 487, 107-118.

[74] it-Ghezala G, Mathura VS, Laporte V, Quadros A, Paris D, Patel N, Volmar CH, Kolippakkam D, Crawford F, Mullan M (2005) Genomic regulation after CD40 stimulation in microglia: Relevance to Alzheimer's disease. Mol Brain Res 140, 73-85.

[75] Lein ES, Zhao XY, Gage FH (2004) Defining a molecular atlas of the hippocampus using DNA microarrays and high-throughput in situ hybridization. J Neurosci $\mathbf{2 4}$, 38793889.

[76] Lein ES, Hawrylycz MJ, Ao N, Ayres M, Bensinger A, Bernard A, Boe AF, Boguski MS, Brockway KS, Byrnes EJ, Chen L, Chen L, Chen TM, Chin MC, Chong J, Crook BE, Czaplinska A, Dang CN, Datta S, Dee NR, Desaki AL, Desta T, Diep E, Dolbeare TA, Donelan MJ, Dong HW, Dougherty JG, Duncan BJ, Ebbert AJ, Eichele G, Estin LK, Faber C, Facer BA, Fields R, Fischer SR, Fliss TP, Frensley C, Gates SN, Glattfelder KJ, Halverson KR, Hart MR, Hohmann JG, Howell MP, Jeung DP, Johnson RA, Karr PT, Kawal R, Kidney JM, Knapik RH, Kuan CL, Lake JH, Laramee AR, Larsen KD, Lau C, Lemon TA, Liang AJ, Liu Y, Luong LT, Michaels J, Morgan JJ, Morgan RJ, Mortrud MT, Mosqueda NF, Ng LL, Ng R, Orta GJ, Overly CC, Pak TH, Parry SE, Pathak SD, Pearson OC, Puchalski RB, Riley ZL, Rockett HR, Rowland SA, Royall JJ, Ruiz MJ, Sarno NR, Schaffnit K, Shapovalova NV, Sivisay T, Slaughterbeck CR, Smith SC, Smith KA, Smith BI, Sodt AJ, Stewart NN, 
Stumpf KR, Sunkin SM, Sutram M, Tam A, Teemer CD, Thaller C, Thompson CL, Varnam LR, Visel A, Whitlock RM, Wohnoutka PE, Wolkey CK, Wong VY, Wood M, Yaylaoglu MB, Young RC, Youngstrom BL, Yuan XF, Zhang B, Zwingman TA, Jones AR (2007) Genome-wide atlas of gene expression in the adult mouse brain. Nature 445, 168-176.

[77] Liang WS, Dunckley T, Beach TG, Grover A, Mastroeni D, Ramsey K, Caselli RJ, Kukull WA, McKeel D, Morris JC, Hulette CM, Schmechel D, Reiman EM, Rogers J, Stephan DA (2008) Altered neuronal gene expression in brain regions differentially affected by Alzheimer's disease: A reference data set. Physiol Genom 33, 240-256.

[78] Miller JA, Horvath S, Geschwind DH (2010) Divergence of human and mouse brain transcriptome highlights Alzheimer disease pathways. Proc Natl Acad Sci U S A 107, 1269812703.

[79] Morciano M, Burre J, Corvey C, Karas M, Zimmermann H, Volknandt W (2005) Immunoisolation of two synaptic vesicle pools from synaptosomes: A proteomics analysis. $J$ Neurochem 95, 1732-1745.

[80] Newrzella D, Pahlavan PS, Krueger C, Boehm C, Sorgenfrei $\mathrm{O}$, Schroeck H, Eisenhardt G, Bischoff N, Vogt G, Wafzig O, Rossner M, Maurer MH, Hiemisch H, Bach A, Kuschinsky W, Schneider A (2007) The functional genome of CA1 and $\mathrm{CA} 3$ neurons under native conditions and in response to ischemia. BMC Genomics 8, 370.

[81] Oldham MC, Horvath S, Geschwind DH (2006) Conservation and evolution of gene coexpression networks in human and chimpanzee brains. Proc Natl Acad Sci U S A 103, 17973-17978.

[82] Oldham MC, Konopka G, Iwamoto K, Langfelder P, Kato T, Horvath S, Geschwind DH (2008) Functional organization of the transcriptome in human brain. Nat Neurosci 11, 12711282.

[83] Parachikova A, Agadjanyan M, Cribbs D, Blurton-Jones M, Perreau V, Rogers J, Beach T, Cotman C (2007) Inflammatory changes parallel the early stages of Alzheimer disease. Neurobiol Aging 28, 1821-1833.

[84] Thomas DM, Francescutti-Verbeem DM, Kuhn DM (2006) Gene expression profile of activated microglia under conditions associated with dopamine neuronal damage. FASEB $J$ 20, 515-517.

[85] Torres-Munoz JE, Van Waveren C, Keegan MG, Bookman RJ, Petito CK (2004) Gene expression profiles in microdissected neurons from human hippocampal subregions. Mol Brain Res 127, 105-114.

[86] Winden KD, Oldham MC, Mirnics K, Ebert PJ, Swan CH, Levitt P, Rubenstein JL, Horvath S, Geschwind DH (2009) The organization of the transcriptional network in specific neuronal classes. Mol Syst Biol 5, 291.

[87] Myers AJ, Gibbs JR, AWebster J, Rohrer K, Zhao A, Marlowe L, Kaleem M, Leung D, Bryden L, Nath P, Zismann VL, Joshipura K, Huentelman MJ, Hu-Lince D, Coon KD, Craig DW, Pearson JV, Holmans P, Heward CB, Reiman EM, Stephan D, Hardy J (2007) A survey of genetic human cortical gene expression. Nat Genet 39, 1494-1499.

[88] Langfelder P, Luo R, Oldham MC, Horvath S (2011) Is my network module preserved and reproducible? PLoS Comput Biol 7, e1001057.

[89] Watkins NA, Gusnanto A, de Bono B, De S, MirandaSaavedra D, Hardie DL, Angenent WGJ, Attwood AP, Ellis PD, Erber W, Foad NS, Garner SF, Isacke CM, Jolley J, Koch K, Macaulay IC, Morley SL, Rendon A, Rice KM, Taylor N, Thijssen-Timmer DC, Tijssen MR, van der Schoot CE, Wernisch L, Winzer T, Dudbridge F, Buckley CD,
Langford CF, Teichmann S, Gottgens B, Ouwehand WH (2009) A HaemAtlas: Characterizing gene expression in differentiated human blood cells. Blood 113, E1-E9.

[90] Ashburner M, Ball CA, Blake JA, Botstein D, Butler H, Cherry JM, Davis AP, Dolinski K, Dwight SS, Eppig JT (2000) Gene ontology: Tool for the unification of biology. The gene ontology consortium. Nat Genet 25, 25-29.

[91] Geissmann F, Jung S, Littman DR (2003) Blood monocytes consist of two principal subsets with distinct migratory properties. Immunity 19, 71-82.

[92] Garton KJ, Gough PJ, Raines EW (2006) Emerging roles for ectodomain shedding in the regulation of inflammatory responses. J Leukoc Biol 79, 1105-1116.

[93] Gomez-Gaviro M, Dominguez-Luis M, Canchado J, Calafat J, Janssen H, Lara-Pezzi E, Fourie A, Tugores A, Valenzuela-Fernandez A, Mollinedo F, Sanchez-Madrid F, az-Gonzalez F (2007) Expression and regulation of the metalloproteinase ADAM-8 during human neutrophil pathophysiological activation and its catalytic activity on L-selectin shedding. J Immunol 178, 8053-8063.

[94] Wang Y, Zhang AC, Ni ZY, Herrera A, Walcheck B (2010) ADAM17 activity and other mechanisms of soluble 1selectin production during death receptor-induced leukocyte apoptosis. J Immunol 184, 4447-4454.

[95] Coppola G, Karyda A, Rademakers R, Wang Q, Baker M, Hutton M, Miller BL, Geschwind DH (2008) Gene expression study on peripheral blood identifies progranulin mutations. Ann Neurol 64, 92-96.

[96] Zanocco-Marani T, Bateman A, Romano G, Valentinis B, He ZH, Baserga R (1999) Biological activities and signaling pathways of the granulin/epithelin precursor. Cancer Res $\mathbf{5 9}$, 5331-5340.

[97] Zhu J, Nathan C, Jin WW, Sim D, Ashcroft GS, Wahl SM, Lacomis L, Erdjument-Bromage H, Tempst P, Wright CD, Ding AH (2002) Conversion of proepithelin to epithelins: Roles of SLPI and elastase in host defense and wound repair. Cell 111, 867-878.

[98] Tang W, Lu Y, Tian QY, Zhang Y, Guo FJ, Liu GY, Syed NM, Lai Y, Lin EA, Kong L, Su J, Yin F, Ding AH, Zanin-Zhorov A, Dustin ML, Tao J, Craft J, Yin Z, Feng JQ, Abramson SB, Yu XP, Liu Cj (2011) The growth factor progranulin binds to TNF receptors and is therapeutic against inflammatory arthritis in mice. Science 332, 478-484.

[99] Chen GY, Nunez G (2010) Sterile inflammation: Sensing and reacting to damage. Nat Rev Immunol 10, 826-837.

[100] Bosetti F, Brizzi F, Barogi S, Mancuso M, Siciliano G, Tendi EA, Murri L, Rapoport SI, Solaini G (2002) Cytochrome $\mathrm{c}$ oxidase and mitochondrial F1F0-ATPase (ATP synthase) activities in platelets and brain from patients with Alzheimer's disease. Neurobiol Aging 23, 371-376.

[101] Mancuso M, Filosto M, Bosetti F, Ceravolo R, Rocchi A, Tognoni G, Manca ML, Solaini G, Siciliano G, Murri L (2003) Decreased platelet cytochrome c oxidase activity is accompanied by increased blood lactate concentration during exercise in patients with Alzheimer disease. Exp Neurol 182, 421-426.

[102] Aksenov MY, Tucker HM, Nair P, Aksenova MV, Butterfield DA, Estus S, Markesbery WR (1999) The expression of several mitochondrial and nuclear genes encoding the subunits of electron transport chain enzyme complexes, cytochrome c oxidase, and NADH dehydrogenase, in different brain regions in Alzheimer's disease. Neurochem Res 24, 767-774.

[103] Liang WS, Reiman EM, Valla J, Dunckley T, Beach TG, Grover A, Niedzielko TL, Schneider LE, Mastroeni D, Caselli R, Kukull W, Morris JC, Hulette CM, Schmechel D, 
Rogers J, Stephan DA (2008) Alzheimer's disease is associated with reduced expression of energy metabolism genes in posterior cingulate neurons. Proc Natl Acad Sci U S A 105, 4441-4446.

[104] Bloudek LM, Spackman DE, Blankenburg M, Sullivan SD (2011) Review and meta-analysis of biomarkers and diagnostic imaging in Alzheimer's disease. J Alzheimers Dis 26, 627-645.

[105] Santos RX, Correia SC, Wang X, Perry G, Smith MA, Moreira PI, Zhu X (2010) Alzheimer's disease: Diverse aspects of mitochondrial malfunctioning. Int J Clin Exp Pathol 3, 570-581.

[106] Song F, Poljak A, Valenzuela M, Mayeux R, Smythe GA, Sachdev PS (2011) Meta-analysis of plasma amyloid-beta levels in Alzheimer's disease. J Alzheimers Dis 26, 365-375.

[107] Loeffen JLCM, Smeitink JAM, Trijbels JMF, Janssen AJM, Triepels RH, Sengers RCA, van den Heuvel LP (2000) Isolated complex I deficiency in children: Clinical, biochemical and genetic aspects. Hum Mutat 15, 123-134.

[108] Benit P, Slama A, Cartault F, Giurgea I, Chretien D, Lebon S, Marsac C, Munnich A, Rotig A, Rustin P (2004) Mutant NDUFS3 subunit of mitochondrial complex I causes Leigh syndrome. J Med Genet 41, 14-17.

[109] Fernandez-Moreira D, Ugalde C, Smeets R, Rodenburg RJ, Lopez-Laso E, Ruiz-Falco ML, Briones P, Martin MA, Smeitink JA, Arenas J (2007) X-linked NDUFA1 gene mutations associated with mitochondrial encephalomyopathy. Ann Neurol 61, 73-83.

[110] Potluri P, Davila A, Ruiz-Pesini E, Mishmar D, O'Hearn S, Hancock S, Simon M, Scheffler IE, Wallace DC, Procaccio V (2009) A novel NDUFA1 mutation leads to a progressive mitochondrial complex I-specific neurodegenerative disease. Mol Genet Metab 96, 189-195.

[111] Haut S, Brivet M, Touati G, Rustin P, Lebon S, GarciaCazorla A, Saudubray JM, Boutron A, Legrand A, Slama A (2003) A deletion in the human QP-C gene causes a complex III deficiency resulting in hypoglycaemia and lactic acidosis. Hum Genet 113, 118-122.

[112] Barel O, Shorer Z, Flusser H, Ofir R, Narkis G, Finer G, Shalev H, Nasasra A, Saada A, Birk OS (2008) Mitochondrial complex III deficiency associated with a homozygous mutation in UQCRQ. Am J Hum Genet 82, 1211-1216.

[113] Saada A, Shaag A, Amon S, Dolfin T, Miller C, Fuchs-Telem D, Lombes A, Elpeleg O (2007) Antenatal mitochondrial disease caused by mitochondrial ribosomal protein (MRPS22) mutation. J Med Genet 44, 784-786.

[114] Smits P, Saada A, Wortmann SB, Heister AJ, Brink M, Pfundt R, Miller C, Haas D, Hantschmann R, Rodenburg RJ, Smeitink JA, van den Heuvel LP (2011) Mutation in mitochondrial ribosomal protein MRPS22 leads to Cornelia de Lange-like phenotype, brain abnormalities and hypertrophic cardiomyopathy. Eur J Hum Genet 19, 394-399.

[115] Di Donato S (2009) Multisystem manifestations of mitochondrial disorders. J Neurol 256, 693-710.

[116] Lenaz G, Genova ML (2010) Structure and organization of mitochondrial respiratory complexes: A new understanding of an old subject. Antioxid Redox Signal 12, 961-1008.

[117] Iuso A, Scacco S, Piccoli C, Bellomo F, Petruzzella V, Trentadue R, Minuto M, Ripoli M, Capitanio N, Zeviani M, Papa S (2006) Dysfunctions of cellular oxidative metabolism in patients with mutations in the NDUFS 1 and NDUFS4 genes of complex I. J Biol Chem 281, 1037410380.

[118] Verkaart S, Koopman WJH, van Emst-de Vries S, Nijtmans LGJ, van den Heuvel LWPJ, Smeitink JAM, Willems PHGM
(2007) Superoxide production is inversely related to complex I activity in inherited complex I deficiency. Biochim Biophys Acta 1772, 373-381.

[119] Tillement L, Lecanu L, Papadopoulos V (2011) Alzheimer's disease: Effects of beta-amyloid on mitochondria. Mitochondrion 11, 13-21.

[120] Su B, Wang X, Zheng L, Perry G, Smith MA, Zhu X (2010) Abnormal mitochondrial dynamics and neurodegenerative diseases. Biochim Biophys Acta 1802, 135-142.

[121] Leuner K, Pantel J, Frey C, Schindowski K, Schulz K, Wegat T, Maurer K, Eckert A, Mueller W (2007) Enhanced apoptosis, oxidative stress and mitochondrial dysfunction in lymphocytes as potential biomarkers for Alzheimer's disease. J Neural Transm Suppl, 207-215.

[122] Leutner S, Schindowski K, Frolich L, Maurer K, Kratzsch T, Eckert A, Muller WE (2005) Enhanced ROS-generation in lymphocytes from Alzheimer's patients. Pharmacopsychiatry 38, 312-315.

[123] Torres LL, Quaglio NB, de Souza GT, Garcia RT, Dati LvMM, Moreira WL, de Melo Loureiro AP, de souzaTalarico JN, Smid J, Porto CS, de Campos Bottino CM, Nitrini R, de Moraes Barros SB, Camarini R, Marcourakis $\mathrm{T}$ (2011) Peripheral oxidative stress biomarkers in mild cognitive impairment and Alzheimer's disease. JAlzheimers Dis 26, 59-68.

[124] Huang HM, Fowler C, Xu H, Zhang H, Gibson GE (2005) Mitochondrial function in fibroblasts with aging in culture and/or Alzheimer's disease. Neurobiol Aging 26, 839848.

[125] Schindowski K, Kratzsch T, Peters J, Steiner B, Leutner S, Touchet N, Maurer K, Czech C, Pradier L, Frolich L, Muller WE, Eckert A (2003) Impact of aging. Neuromol Med 4, 161-177.

[126] Sultana R, Mecocci P, Mangialasche F, Cecchetti R, Baglioni M, Butterfield D (2011) Increased protein and lipid oxidative damage in mitochondria isolated from lymphocytes from patients with Alzheimer's disease: Insights into the role of oxidative stress in Alzheimer's disease and initial investigations into a potential biomarker for this dementing disorder. J Alzheimers Dis 24, 77-84.

[127] Eckert A, Steiner B, Marques C, Leutz S, Romig H, Haass C, Muller WE (2001) Elevated vulnerability to oxidative stress-induced cell death and activation of caspase- 3 by the Swedish amyloid precursor protein mutation. J Neurosci Res 64, 183-192.

[128] Eckert A, Schindowski K, Leutner S, Luckhaus C, Touchet N, Czech C, Muller WE (2001) Alzheimer's disease-like alterations in peripheral cells from presenilin-1 transgenic mice. Neurobiol Dis 8, 331-342.

[129] Eckert A, Keil U, Marques CA, Bonert A, Frey C, Schussel K, Muller WE (2003) Mitochondrial dysfunction, apoptotic cell death, and Alzheimer's disease. Biochem Pharmacol 66, 1627-1634.

[130] Schindowski K, Peters J, Gorriz C, Schramm U, Weinandl T, Leutner S, Maurer K, Frolich L, Muller WE, Eckert A (2006) Apoptosis of CD4(+) $\mathrm{T}$ and natural killer cells in Alzheimer's disease. Pharmacopsychiatry 39, 220-228.

[131] Weinmann P, Scharffetter-Kochanek K, Forlow SB, Peters T, Walzog B (2003) A role for apoptosis in the control of neutrophil homeostasis in the circulation: Insights from CD18-deficient mice. Blood 101, 739-746.

[132] Renshaw SA, Timmons SJ, Eaton V, Usher LR, Akil M, Bingle CD, Whyte MKB (2000) Inflammatory neutrophils retain susceptibility to apoptosis mediated via the Fas death receptor. J Leukoc Biol 67, 662-668. 
[133] West AP, Shadel GS, Ghosh S (2011) Mitochondria in innate immune responses. Nat Rev Immunol 11, 389-402.

[134] West AP, Brodsky IE, Rahner C, Woo DK, ErdjumentBromage H, Tempst P, Walsh MC, Choi Y, Shadel GS, Ghosh S (2011) TLR signalling augments macrophage bactericidal activity through mitochondrial ROS. Nature 472, U476-U543.

[135] Emre Y, Hurtaud C, Nubel T, Criscuolo F, Ricquier D, Cassard-Doulcier AM (2007) Mitochondria contribute to LPS-induced MAPK activation via uncoupling protein UCP2 in macrophages. Biochem J 402, 271-278.

[136] Sonoda J, Laganiere J, Mehl IR, Barish GD, Chong LW, Li XL, Scheffler IE, Mock DC, Bataille AR, Robert F, Lee CH, Giguere V, Evans RM (2007) Nuclear receptor ERR alpha and coactivator PGC-1 beta are effectors of IFN-gammainduced host defense. Genes Devel 21, 1909-1920.

[137] Zhou RB, Yazdi AS, Menu P, Tschopp J (2011) A role for mitochondria in NLRP3 inflammasome activation. Nature 469, 221-225.

[138] Hawkins BJ, Solt LA, Chowdhury L, Kazi AS, Abid MR, Aird WC, May MJ, Foskett JK, Madesh M (2007) G protein-coupled receptor $\mathrm{Ca} 2+-$ linked mitochondrial reactive oxygen species are essential for endothelial/leukocyte adherence. Mol Cell Biol 27, 7582-7593.

[139] Fossati G, Moulding DA, Spiller DG, Moots RJ, White MRH, Edwards SW (2003) The mitochondrial network of human neutrophils: Role in chemotaxis, phagocytosis, respiratory burst activation, and commitment to apoptosis. $J$ Immunol 170, 1964-1972.

[140] Van Raam BJ, Sluiter W, de Wit E, Roos D, Verhoeven AJ, Kuijpers TW (2008) Mitochondrial membrane potential in human neutrophils is maintained by complex III activity in the absence of supercomplex organisation. PLOS ONE 3, e2013.

[141] McDonald B, Pittman K, Menezes GB, Hirota SA, Slaba I, Waterhouse CCM, Beck PL, Muruve DA, Kubes P (2010) Intravascular danger signals guide neutrophils to sites of sterile inflammation. Science 3, 362-366.

[142] Soscia SJ, Kirby JE, Washicosky KJ, Tucker SM, Ingelsson M, Hyman B, Burton MA, Goldstein LE, Duong S, Tanzi RE, Moir RD (2010) The Alzheimer's disease-associated amyloid beta-protein is an antimicrobial peptide. PLOS ONE 5, e9505.

[143] Akiyama H, Barger S, Barnum S, Bradt B, Bauer J, Cole GM, Cooper NR, Eikelenboom P, Emmerling M, Fiebich BL, Finch CE, Frautschy S, Griffin WST, Hampel H, Hull M, Landreth G, Lue LF, Mrak R, Mackenzie IR, Mcgeer PL, O'Banion MK, Pachter J, Pasinetti G, Plata-Salaman C, Rogers J, Rydel R, Shen Y, Streit W, Strohmeyer R, Tooyoma I, Van Muiswinkel FL, Veerhuis R, Walker D, Webster S, Wegrzyniak B, Wenk G, Wyss-Coray T, Neuroinflammation WG (2000) Inflammation and Alzheimer's disease. Neurobiol Aging 21, 383-421.

[144] Fiala M, Zhang L, Gan XH, Sherry B, Taub D, Graves MC, Hama S, Way D, Weinand M, Witte M, Lorton D, Kuo YM, Roher AE (1998) Amyloid-beta induces chemokine secretion and monocyte migration across a human blood-brain barrier model. Mol Med 4, 480-489.

[145] Ito S, Sawada M, Haneda M, Ishida Y, Isobe K (2006) Amyloid-beta peptides induce several chemokine mRNA expressions in the primary microglia and $\mathrm{Ra} 2$ cell line via the PI3K/Akt and/or ERK pathway. Neurosci Res 56, 294299.

[146] Smits HA, Rijsmus A, van Loon JH, Wat JWY, Verhoef J, Boven LA, Nottet HSLM (2002) Amyloid-beta-induced chemokine production in primary human macrophages and astrocytes. J Neuroimmunol 127, 160-168.

[147] Walker DG, Link J, Lue LF, sing-Hernandez JE, Boyes BE (2006) Gene expression changes by amyloid beta peptidestimulated human postmortem brain microglia identify activation of multiple inflammatory processes. J Leukoc Biol 79, 596-610.

[148] Kalehua AN, Nagel JE, Whelchel LM, Gides JJ, Pyle RS, Smith RJ, Kusiak JW, Taub DD (2004) Monocyte chemoattractant protein-1 and macrophage inflammatory protein-2 are involved in both excitotoxin-induced neurodegeneration and regeneration. Exp Cell Res 297, 197-211.

[149] Swardfager W, Lanctot K, Rothenburg L, Wong A, Cappell J, Herrmann N (2010) A Meta-analysis of cytokines in Alzheimer's disease. Biol Psychiatry 68, 930-941.

[150] Zuliani G, Cavalieri M, Galvani M, Passaro A, Munari MR, Bosi C, Zurlo A, Fellin R (2008) Markers of endothelial dysfunction in older subjects with late onset Alzheimer's disease or vascular dementia. J Neurol Sci 272, 164-170.

[151] Chen M, Inestrosa NC, Ross GS, Fernandez HL (1995) Platelets are the primary source of amyloid beta-peptide in human blood. Biochem Biophys Res Commun 213, 96-103.

[152] Cutler P, Akuffo EL, Bodnar WM, Briggs DM, Davis JB, Debouck CM, Fox SM, Gibson RA, Gormley DA, Holbrook JD, Hunter AJ, Kinsey EE, Pripffial R, Richardson JC, Roses AD, Smith MA, Sokanas N, Wille DR, Wu W, Yates JW, Gloger IS (2008) Proteomic identification and early validation of complement 1 inhibitor and pigment epithelium -derived factor: Two novel biomarkers of Alzheimer's disease in human plasma. Proteomics Clin Appl 2, 467-477.

[153] German DC, Gurnani P, Nandi A, Garner HR, Fisher W, azArrastia R, O'Suilleabhain P, Rosenblatt KP (2007) Serum biomarkers for Alzheimer's disease: Proteomic discovery. Biomed Pharmacotherapy 61, 383-389.

[154] Giri R, Shen YM, Stins M, Yan SD, Schmidt AM, Stern D, Kim KS, Zlokovic B, Kalra VK (2000) betaAmyloid-induced migration of monocytes across human brain endothelial cells involves RAGE and PECAM-1. Am J Physiol Cell Physiol 279, C1772-C1781.

[155] Lebson L, Nash K, Kamath S, Herber D, Carty N, Lee DC, Li QY, Szekeres K, Jinwal U, Koren J, Dickey CA, Gottschall PE, Morgan D, Gordon MN (2010) Trafficking CD11b-positive blood cells deliver therapeutic genes to the brain of amyloid-depositing transgenic mice. J Neurosci $\mathbf{3 0}$, 9651-9658.

[156] Liu YJ, Guo DW, Tian L, Shang DS, Zhao WD, Li B, Fang WG, Zhu L, Chen YH (2010) Peripheral T cells derived from Alzheimer's disease patients overexpress CXCR2 contributing to its transendothelial migration, which is microglial TNF-alpha-dependent. Neurobiol Aging 31, 175-188.

[157] Togo T, Akiyama H, Iseki E, Kondo H, Ikeda K, Kato M, Oda T, Tsuchiya K, Kosaka K (2002) Occurrence of T cells in the brain of Alzheimer's disease and other neurological diseases. J Neuroimmunol 124, 83-92.

[158] Harold D, Abraham R, Hollingworth P, Sims R, Gerrish A, Hamshere ML, Pahwa JS, Moskvina V, Dowzell K, Williams A, Jones N, Thomas C, Stretton A, Morgan AR, Lovestone S, Powell J, Proitsi P, Lupton MK, Brayne C, Rubinsztein DC, Gill M, Lawlor B, Lynch A, Morgan K, Brown KS, Passmore PA, Craig D, McGuinness B, Todd S, Holmes C, Mann D, Smith AD, Love S, Kehoe PG, Hardy J, Mead S, Fox N, Rossor M, Collinge J, Maier W, Jessen F, Schurmann B, van den Bussche H, Heuser I, Kornhuber J, Wiltfang J, Dichgans M, Frolich L, Hampel H, Hull M, Rujescu D, Goate AM, Kauwe JSK, Cruchaga C, Nowotny P, Morris JC, 
Mayo K, Sleegers K, Bettens K, Engelborghs S, De Deyn PP, Van Broeckhoven C, Livingston G, Bass NJ, Gurling H, McQuillin A, Gwilliam R, Deloukas P, Al-Chalabi A, Shaw CE, Tsolaki M, Singleton AB, Guerreiro R, Muhleisen TW, Nothen MM, Moebus S, Jockel KH, Klopp N, Wichmann HE, Carrasquillo MM, Pankratz VS, Younkin SG, Holmans PA, O'Donovan M, Owen MJ, Williams J (2009) Genome-wide association study identifies variants at CLU and PICALM associated with Alzheimer's disease. Nat Genet 41, 1088-1093.

[159] Hollingworth P, Harold D, Sims R, Gerrish A, Lambert JC, Carrasquillo MM, Abraham R, Hamshere ML, Pahwa JS, Moskvina V, Dowzell K, Jones N, Stretton A, Thomas C, Richards A, Ivanov D, Widdowson C, Chapman J, Lovestone S, Powell J, Proitsi P, Lupton MK, Brayne C, Rubinsztein DC, Gill M, Lawlor B, Lynch A, Brown KS, Passmore PA, Craig D, McGuinness B, Todd S, Holmes C, Mann D, Smith AD, Beaumont H, Warden D, Wilcock G, Love S, Kehoe PG, Hooper NM, Vardy ERLC, Hardy J, Mead S, Fox NC, Rossor M, Collinge J, Maier W, Jessen F, Ruther E, Schurmann B, Heun R, Kolsch H, van den Bussche H, Heuser I, Kornhuber J, Wiltfang J, Dichgans M, Frolich L, Hampel H, Gallacher J, Hull M, Rujescu D, Giegling I, Goate AM, Kauwe JSK, Cruchaga C, Nowotny P, Morris JC, Mayo K, Sleegers K, Bettens K, Engelborghs S, De Deyn PP, Van Broeckhoven C, Livingston G, Bass NJ, Gurling H, McQuillin A, Gwilliam R, Deloukas P, AlChalabi A, Shaw CE, Tsolaki M, Singleton AB, Guerreiro R, Muhleisen TW, Nothen MM, Moebus S, Jockel KH, Klopp N, Wichmann HE, Pankratz VS, Sando SB, Aasly JO, Barcikowska M, Wszolek ZK, Dickson DW, Graff-Radford NR, Petersen RC, van Duijn CM, Breteler MMB, Ikram MA, DeStefano AL, Fitzpatrick AL, Lopez O, Launer LJ, Seshadri S, Berr C, Campion D, Epelbaum J, Dartigues JF, Tzourio C, Alperovitch A, Lathrop M, Feulner TM, Friedrich P, Riehle C, Krawczak M, Schreiber S, Mayhaus M, Nicolhaus S, Wagenpfeil S, Steinberg S, Stefansson H, Stefansson K, Snaedal J, Bjornsson S, Jonsson PV, Chouraki V, Genier-Boley B, Hiltunen M, Soininen H, Combarros O, Zelenika D, Delepine M, Bullido MJ, Pasquier F, Mateo I, Frank-Garcia A, Porcellini E, Hanon O, Coto E, Alvarez V, Bosco P, Siciliano G, Mancuso M, Panza F, Solfrizzi V, Nacmias B, Sorbi S, Bossu P, Piccardi P, Arosio B, Annoni G, Seripa D, Pilotto A, Scarpini E, Galimberti D, Brice A, Hannequin D, Licastro F, Jones L, Holmans PA, Jonsson T, Riemenschneider M, Morgan K, Younkin SG, Owen MJ, O’Donovan M, Amouyel P, Williams J (2011) Common variants at $\mathrm{ABCA} 7, \mathrm{MS} 4 \mathrm{~A} 6 \mathrm{~A} / \mathrm{MS} 4 \mathrm{~A} 4 \mathrm{E}, \mathrm{EPHA} 1, \mathrm{CD} 33$ and CD2AP are associated with Alzheimer's disease. Nat Genet 43, 429-435.

[160] Jones L, Holmans PA, Hamshere ML, Harold D, Moskvina V, Ivanov D, Pocklington A, Abraham R, Hollingworth P, Sims R, Gerrish A, Pahwa JS, Jones N, Stretton A, Morgan AR, Lovestone S, Powell J, Proitsi P, Lupton MK, Brayne C, Rubinsztein DC, Gill M, Lawlor B, Lynch A, Morgan K, Brown KS, Passmore PA, Craig D, McGuinness B, Todd S, Holmes C, Mann D, Smith A, Love S, Kehoe PG, Mead S, Fox N, Rossor M, Collinge J, Maier W, Jessen F, Schuermann B, van den Bussche H, Heuser I, Peters O, Kornhuber J, Wiltfang J, Dichgans M, Froelich L, Hampel H, Huell M, Rujescu D, Goate AM, Kauwe JS, Cruchaga C, Nowotny P, Morris JC, Mayo K, Livingston G, Bass NJ, Gurling H, McQuillin A, Gwilliam R, Deloukas P, Al-Chalabi A, Shaw CE, Singleton AB, Guerreiro R, Muehleisen TW, Noethen MM, Moebus S, Joeckel KH, Klopp N, Wichmann
H, Ruether E, Carrasquillo MM, Pankratz V, Younkin SG, Hardy J, O'Donovan MC, Owen MJ, Williams J (2010) Genetic evidence implicates the immune system and cholesterol metabolism in the aetiology of Alzheimer's disease. PLOS ONE 5, e13950.

[161] Jun G, Naj AC, Beecham GW, Wang LS, Buros J, Gallins PJ, Buxbaum JD, Ertekin-Taner N, Fallin D, Friedland R, Inzelberg R, Kramer P, Rogaeva E, George-Hyslop PS, Cantwell LB, Dombroski BA, Saykin AJ, Reiman EM, Bennett DA, Morris JC, Lunetta KL, Martin ER, Montine TJ, Goate AM, Blacker D, Tsuang DW, Beekly D, Cupples L, Hakonarson H, Kukull W, Foroud TM, Haines J, Mayeux R, Farrer LA, Pericak-Vance MA, Schellenberg GD (2010) Meta-analysis confirms CR1, CLU, and PICALM as Alzheimer disease risk loci and reveals interactions with APOE genotypes. Arch Neurol 67, 1473-1484.

[162] Lambert JC, Heath S, Even G, Campion D, Sleegers K, Hiltunen M, Combarros O, Zelenika D, Bullido MJ, Tavernier B, Letenneur L, Bettens K, Berr C, Pasquier F, Fievet N, Barberger-Gateau P, Engelborghs S, De Deyn P, Mateo I, Franck A, Helisalmi S, Porcellini E, Hanon O, de Pancorbo MM, Lendon C, Dufouil C, Jaillard C, Leveillard T, Alvarez V, Bosco P, Mancuso M, Panza F, Nacmias B, Bossu P, Piccardi P, Annoni G, Seripa D, Galimberti D, Hannequin D, Licastro F, Soininen H, Ritchie K, Blanche H, Dartigues JF, Tzourio C, Gut I, Van Broeckhoven C, Alperovitch A, Lathrop M, Amouyel P (2009) Genome-wide association study identifies variants at CLU and CR1 associated with Alzheimer's disease. Nat Genet 41, 1094-1099.

[163] Naj AC, Jun G, Beecham GW, Wang LS, Vardarajan BN, Buros J, Gallins PJ, Buxbaum JD, Jarvik GP, Crane PK, Larson EB, Bird TD, Boeve BF, Graff-Radford NR, De Jager PL, Evans D, Schneider JA, Carrasquillo MM, ErtekinTaner N, Younkin SG, Cruchaga C, Kauwe JSK, Nowotny P, Kramer P, Hardy J, Huentelman MJ, Myers AJ, Barmada MM, Demirci FY, Baldwin CT, Green RC, Rogaeva E, George-Hyslop PS, Arnold SE, Barber R, Beach T, Bigio EH, Bowen JD, Boxer A, Burke JR, Cairns NJ, Carlson CS, Carney RM, Carroll SL, Chui HC, Clark DG, Corneveaux J, Cotman CW, Cummings JL, DeCarli C, Dekosky ST, azArrastia R, Dick M, Dickson DW, Ellis WG, Faber KM, Fallon KB, Farlow MR, Ferris S, Frosch MP, Galasko DR, Ganguli M, Gearing M, Geschwind DH, Ghetti B, Gilbert JR, Gilman S, Giordani B, Glass JD, Growdon JH, Hamilton RL, Harrell LE, Head E, Honig LS, Hulette CM, Hyman BT, Jicha GA, Jin LW, Johnson N, Karlawish J, Karydas A, Kaye JA, Kim R, Koo EH, Kowall NW, Lah JJ, Levey AI, Lieberman AP, Lopez OL, Mack WJ, Marson DC, Martiniuk F, Mash DC, Masliah E, McCormick WC, McCurry SM, McDavid AN, McKee AC, Mesulam M, Miller BL, Miller CA, Miller JW, Parisi JE, Perl DP, Peskind E, Petersen RC, Poon WW, Quinn JF, Rajbhandary RA, Raskind M, Reisberg B, Ringman JM, Roberson ED, Rosenberg RN, Sano M, Schneider LS, Seeley W, Shelanski ML, Slifer MA, Smith CD, Sonnen JA, Spina S, Stern RA, Tanzi RE, Trojanowski JQ, Troncoso JC, Van Deerlin VM, Vinters HV, Vonsattel JP, Weintraub S, Welsh-Bohmer KA, Williamson J, Woltjer RL, Cantwell LB, Dombroski BA, Beekly D, Lunetta KL, Martin ER, Kamboh MI, Saykin AJ, Reiman EM, Bennett DA, Morris JC, Montine TJ, Goate AM, Blacker D, Tsuang DW, Hakonarson H, Kukull WA, Foroud TM, Haines JL, Mayeux R, Pericak-Vance MA, Farrer LA, Schellenberg GD (2011) Common variants at MS4A4/MS4A6E, CD2AP, CD33 and EPHA1 are associated with late-onset Alzheimer's disease. Nat Genet 43, 436-441. 
[164] Seshadri S, Fitzpatrick AL, Ikram M, DeStefano AL, Gudnason V, Boada M, Bis JC, Smith AV, Carassquillo MM, Lambert JC, Harold D, Schrijvers EM, Ramirez-Lorca R, Debette S, Longstreth W, Janssens A, Pankratz V, Dartigues JF, Hollingworth P, Aspelund T, Hernandez I, Beiser A, Kuller LH, Koudstaal PJ, Dickson DW, Tzourio C, Abraham R, Antunez C, Du Y, Rotter JI, Aulchenko YS, Harris TB, Petersen RC, Berr C, Owen MJ, Lopez-Arrieta J, Varadarajan BN, Becker JT, Rivadeneira F, Nalls MA, Graff-Radford NR, Campion D, Auerbach S, Rice K, Hofman A, Jonsson PV, Schmidt H, Lathrop M, Mosley TH, Au R, Psaty BM, Uitterlinden AG, Farrer LA, Lumley T, Ruiz A, Williams J, Amouyel P, Younkin SG, Wolf PA, Launer LJ, Lopez OL, van Duijn CM, Breteler MM (2010) Genome-wide analysis of genetic loci associated with Alzheimer disease. JAMA 303, 1832-1840.

[165] Reitz C, Cheng R, Rogaeva E, Lee JH, Tokuhiro S, Zou FG, Bettens K, Sleegers K, Tan EK, Kimura R, Shibata N, Arai H, Kamboh MI, Prince JA, Maier W, Riemenschneider M, Owen M, Harold D, Hollingworth P, Cellini E, Sorbi S, Nacmias B, Takeda M, Pericak-Vance MA, Haines JL, Younkin S, Williams J, van Broeckhoven C, Farrer LA, St George-Hyslop PH, Mayeux R (2011) Meta-analysis of the association between variants in sorl1 and Alzheimer disease. Arch Neurol 68, 99-106.

[166] Schmidt V, Baum K, Lao A, Rateitschak K, Schmitz Y, Teichmann A, Wiesner B, Petersen CM, Nykjaer A, Wolf J, Wolkenhauer O, Willnow TE (2012) Quantitative modelling of amyloidogenic processing and its influence by SORLA in Alzheimer's disease. EMBO J 31, 187-200.

[167] Mayeux R, Schupf N (2011) Blood-based biomarkers for Alzheimer's disease: Plasma Abeta40 and Abeta42, and genetic variants. Neurobiol Aging 32(Suppl 1), S10-S19.

[168] Mayeux R (1999) Plasma amyloid [beta]-peptide 1-42 and incipient Alzheimer's disease. Ann Neurol 46, 412-416.

[169] Eikelenboom P, Veerhuis R (1996) The role of complement and activated microglia in the pathogenesis of Alzheimer's disease. Neurobiol Aging 17, 673-680.

[170] Abbott NJ, Patabendige AAK, Dolman DEM, Yusof SR, Begley DJ (2010) Structure and function of the blood-brain barrier. Neurobiol Dis 37, 13-25.

[171] Kalaria RN (1999) The blood-brain barrier and cerebrovascular pathology in Alzheimer's disease. Ann N Y Acad Sci 893, 113-125.

[172] Ewers M, Mielke MM, Hampel H (2010) Blood-based biomarkers of microvascular pathology in Alzheimer's disease. Exp Gerontol 45, 75-79.

[173] Ryu JK, McLarnon JG (2009) A leaky blood-brain barrier, fibrinogen infiltration and microglial reactivity in inflamed Alzheimer's disease brain. J Cell Mol Med 13, 2911-2925.

[174] Thomas T, Sutton ET, Bryant MW, Rhodin JAG (1997) In vivo vascular damage, leukocyte activation and inflammatory response induced by beta-amyloid. J Submicrosc Cytol Pathol 29, 293-304.

[175] Rossi B, Angiari S, Zenaro E, Budui SL, Constantin G (2011) Vascular inflammation in central nervous system diseases: Adhesion receptors controlling leukocyte-endothelial interactions. J Leukoc Biol 89, 539-556.

[176] Priller J, Flugel A, Wehner T, Boentert M, Haas CA, Prinz M, Fernandez-Klett F, Prass K, Bechmann I, de Boer BA, Frotscher M, Kreutzberg GW, Persons DA, Dirnagl U (2001) Targeting gene-modified hematopoietic cells to the central nervous system: Use of green fluorescent protein uncovers microglial engraftment. Nat Med 7, 1356-1361.

[177] Simard AR, Soulet D, Gowing G, Julien JP, Rivest S (2006) Bone marrow-derived microglia play a critical role in restricting senile plaque formation in Alzheimer's disease. Neuron 49, 489-502.

[178] Stalder AK, Ermini F, Bondolfi L, Krenger W, Burbach GJ, Deller T, Coomaraswamy J, Staufenbiel M, Landmann R, Jucker M (2005) Invasion of hematopoietic cells into the brain of amyloid precursor protein transgenic mice. $J$ Neurosci 25, 11125-11132.

[179] Itagaki S, Mcgeer PL, Akiyama H (1988) Presence of T-cytotoxic suppressor and leukocyte common antigen positive cells in Alzheimer's disease brain-tissue. Neurosci Lett 91, 259-264.

[180] Li M, Shang DS, Zhao WD, Tian L, Li B, Fang WG, Zhu L, Man SM, Chen YH (2009) Amyloid beta interaction with receptor for advanced glycation end products up-regulates brain endothelial ccr5 expression and promotes $\mathrm{T}$ cells crossing the blood-brain barrier. J Immunol 182, 5778-5788.

[181] Rogers J, Lubernarod J, Styren SD, Civin WH (1988) Expression of immune system-associated antigens by cells of the human central nervous-system - relationship to the pathology of Alzheimer's disease. Neurobiol Aging 9, 339349.

[182] Town T, Tan J, Flavell RA, Mullan M (2005) T-cells in Alzheimer's disease. Neuromol Med 7, 255-264.

[183] Hensley K, Maidt ML, Yu Z, Sang H, Markesbery WR, Floyd RA (1998) Electrochemical analysis of protein nitrotyrosine and dityrosine in the Alzheimer brain indicates region-specific accumulation. J Neurosci 18, 8126-8132.

[184] Ajami B, Bennett JL, Krieger C, Tetzlaff W, Rossi FMV (2007) Local self-renewal can sustain CNS microglia maintenance and function throughout adult life. Nat Neurosci 10, 1538-1543.

[185] Hu X, Pickering EH, Hall SK, Naik S, Liu YC, Soares H, Katz E, Paciga SA, Liu W, Aisen PS, Bales KR, Samad TA, John SL (2011) Genome-wide association study identifies multiple novel loci associated with disease progression in subjects with mild cognitive impairment. Transl Psychiatry 1, e54.

[186] Taylor MJ, Perrais D, Merrifield CJ (2011) A high precision survey of the molecular dynamics of mammalian clathrinmediated endocytosis. Plos Biology 9, e1000604.

[187] Treusch S, Hamamichi S, Goodman JL, Matlack KE, Chung CY, Baru V, Shulman JM, Parrado A, Bevis BJ, Valastyan JS, Han H, Lindhagen-Persson M, Reiman EM, Evans DA, Bennett DA, Olofsson A, DeJager PL, Tanzi RE, Caldwell KA, Caldwell GA, Lindquist S (2011) Functional links between Abeta toxicity, endocytic trafficking, and Alzheimer's disease risk factors in yeast. Science 334, 1241-1245.

[188] Muller AJ, Baker JF, DuHadaway JB, Ge K, Farmer G, Donover PS, Meade R, Reid C, Grzanna R, Roach AH, Shah N, Soler AP, Prendergast GC (2003) Targeted disruption of the murine Bin1/Amphiphysin II gene does not disable endocytosis but results in embryonic cardiomyopathy with aberrant myofibril formation. Mol Cell Biol 23, 4295-4306.

[189] Magaki S, Yellon SM, Mueller C, Kirsch WM (2008) Immunophenotypes in the circulation of patients with mild cognitive impairment. J Psychiatric Res 42, 240-246. 